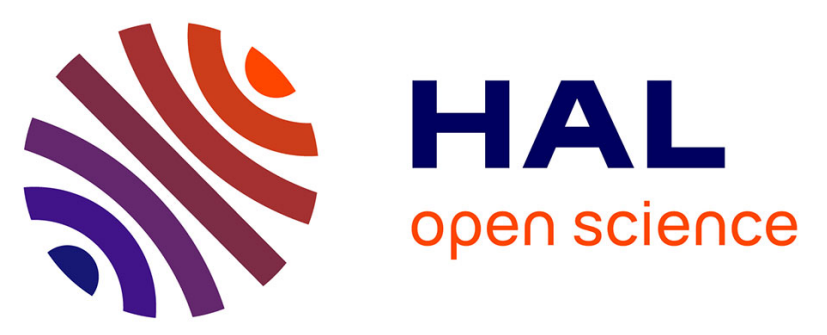

\title{
Reductive Termination of Cyanoisopropyl Radicals by Copper(I) Complexes and Proton Donors: Organometallic Intermediates or Coupled Proton-Electron Transfer?
}

Lucas Thevenin, Christophe Fliedel, Marco Fantin, Thomas Ribelli, Krzysztof Matyjaszewski, Rinaldo Poli

\section{To cite this version:}

Lucas Thevenin, Christophe Fliedel, Marco Fantin, Thomas Ribelli, Krzysztof Matyjaszewski, et al.. Reductive Termination of Cyanoisopropyl Radicals by Copper(I) Complexes and Proton Donors: Organometallic Intermediates or Coupled Proton-Electron Transfer?. Inorganic Chemistry, 2019, 58 (9), pp.6445-6457. 10.1021/acs.inorgchem.9b00660 . hal-02335247

\section{HAL Id: hal-02335247 \\ https://hal.science/hal-02335247}

Submitted on 30 Oct 2020

HAL is a multi-disciplinary open access archive for the deposit and dissemination of scientific research documents, whether they are published or not. The documents may come from teaching and research institutions in France or abroad, or from public or private research centers.
L'archive ouverte pluridisciplinaire HAL, est destinée au dépôt et à la diffusion de documents scientifiques de niveau recherche, publiés ou non, émanant des établissements d'enseignement et de recherche français ou étrangers, des laboratoires publics ou privés. 


\title{
Reductive termination of cyanoisopropyl radicals by
}

\author{
copper(I) complexes and proton donors:
}

\section{organometallic intermediates or coupled proton-}

\section{electron transfer?}

Lucas Thevenin, ${ }^{\dagger}$ Christophe Fliedel,${ }^{\dagger}$ Marco Fantin, ${ }^{*}$ Thomas G. Ribelli, ${ }^{*}$ Krzysztof

Matyjaszewski, ${ }^{\ddagger}$ Rinaldo Poli ${ }^{\dagger} *$

${ }^{\dagger}$ CNRS, LCC (Laboratoire de Chimie de Coordination), Université de Toulouse, UPS, INPT, 205 Route de Narbonne, BP 44099, F-31077, Toulouse Cedex 4, France.

¥Department of Chemistry, Carnegie Mellon University, 4400 Fifth Avenue, Pittsburgh, PA 15213, United States.

$\S$ Institut Universitaire de France, 1, rue Descartes, 75231 Paris Cedex 05, France.

KEYWORDS. Copper, Coupled Proton-Electron Transfer, Protonolysis, Organocopper(II) complexes, Radical 
ABSTRACT. Cyanoisopropyl radicals, generated thermally by the decomposition of azobis(isobutyronitrile) (AIBN), participate in reductive radical termination (RRT) under the combined effect of copper(I) complexes and proton donors (water, methanol, triethylammonium salts) in acetonitrile or benzene. The investigated copper complexes were formed in situ from $\left[\mathrm{Cu}^{\mathrm{I}}(\mathrm{MeCN})_{4}\right]^{+} \mathrm{BF}_{4}^{-}$in $\mathrm{CD}_{3} \mathrm{CN}$ or $\mathrm{Cu}^{\mathrm{I}} \mathrm{Br}$ in $\mathrm{C}_{6} \mathrm{D}_{6}$ using tris[2-(dimethylamino)ethyl]amine (Me 6 TREN), tris(2-pyridylmethyl)amine (TPMA) and 2,2'-bipyridine (BIPY) ligands. Upon keeping all other conditions constants, the impact of RRT is much greater for the $\mathrm{Me}_{6} \mathrm{TREN}$ and TPMA systems than for the BIPY system. RRT scales with the proton donor acidity $\left(\mathrm{Et}_{3} \mathrm{NH}^{+}>>\right.$ $\left.\mathrm{H}_{2} \mathrm{O}>\mathrm{CH}_{3} \mathrm{OH}\right)$, it is reduced by deuteration $\left(\mathrm{H}_{2} \mathrm{O}>\mathrm{D}_{2} \mathrm{O}\right.$ and $\left.\mathrm{CH}_{3} \mathrm{OH}>\mathrm{CD}_{3} \mathrm{OD}\right)$ and it is more efficient in $\mathrm{C}_{6} \mathrm{D}_{6}$ than in $\mathrm{CD}_{3} \mathrm{CN}$. The collective evidence gathered in this study excludes the intervention of an outer-sphere proton-coupled electron transfer (OS-PCET), while an innersphere PCET (IS-PCET) cannot be excluded for coordinating proton donors (water and methanol). On the other hand, the strong impact of RRT for the non-coordinating $\mathrm{Et}_{3} \mathrm{NH}^{+}$in $\mathrm{CD}_{3} \mathrm{CN}$ results from the formation of an intermediate $\mathrm{Cu}^{\mathrm{I}}$-radical adduct, suggested by DFT calculations to involve binding via the $\mathrm{N}$ atom to yield keteniminato $\left[\mathrm{L} / \mathrm{Cu}-\mathrm{N}=\mathrm{C}=\mathrm{CMe}_{2}\right]^{+}$derivatives with only partial spin delocalization onto the $\mathrm{Cu}$ atom. 


\section{Introduction}

Organic radicals can interact with transition metal complexes in a number of different ways. ${ }^{1}$ Of particular interest to us are reversible reactions that yield dormant species, allowing radical polymerization processes to become controlled via the persistent radical effect. ${ }^{2}$ These types of polymerization processes are known as "Reversible Deactivation Radical Polymerizations" (RDRPs). ${ }^{3}$ Two such reactions are atom transfer from a halogen-containing oxidized metal complex, Y-Mt ${ }^{\mathrm{x}+1} / \mathrm{L}$, to yield the reduced complex $\mathrm{Mt}^{\mathrm{x}} / \mathrm{L}$ and an alkyl halide $\mathrm{R}-\mathrm{Y}$ (Scheme $1 ; \mathrm{Y}=$ halogen, $\mathrm{Mt}=$ metal, $\mathrm{L}=$ coordinating ligand, $\mathrm{R}=$ organic radical, $\mathrm{x}$ and $\mathrm{x}+1=$ formal oxidation states) and direct metal-carbon bond formation to form an organometallic species, Scheme 2. The corresponding RDRP strategies are respectively known as "Atom Transfer Radical Polymerization" (ATRP) ${ }^{4-9}$ and "Organometallic-Mediated Radical Polymerization" (OMRP). ${ }^{10-}$

${ }^{12}$ These two mechanisms were shown to constructively interplay for certain metal systems. ${ }^{13,14}$ One of the most versatile metals for ATRP is copper, shuttling between the oxidation states +1 and +2 , whereas OMRP has so far been particularly successful using $\mathrm{Co}$ II/Co ${ }^{\mathrm{III}}$ systems and has not found successful implementations for copper complexes. ${ }^{15}$

$$
\mathrm{R}^{\bullet}+\mathrm{Y}-\mathrm{Mt}^{\mathrm{x}+1} / \mathrm{L} \underset{k_{\mathrm{a}, \mathrm{ATRP}} \underset{\mathrm{da}, \mathrm{ATRP}}{\rightleftarrows}}{\rightleftarrows} \mathrm{R}-\mathrm{Y}+\mathrm{Mt}^{\mathrm{x} / \mathrm{L}} \quad K_{\mathrm{ATRP}}=\frac{k_{\mathrm{a}, \mathrm{ATRP}}}{k_{\mathrm{da}, \mathrm{ATRP}}}
$$

Scheme 1. Reaction between an organic radical and a halogen-containing metal complex leading to atom transfer.

$$
\mathrm{R}^{\bullet}+\mathrm{Mt}^{\mathrm{x} / \mathrm{L}} \underset{k_{\mathrm{a}, \mathrm{OMRP}}}{\stackrel{k_{\mathrm{da}, \mathrm{OMRP}}}{\rightleftarrows}} \mathrm{R}-\mathrm{Mt}^{\mathrm{x}+1} / \mathrm{L} \quad K_{\mathrm{OMRP}}=\frac{k_{\mathrm{a}, \mathrm{OMRP}}}{k_{\mathrm{da}, \mathrm{OMRP}}}
$$


Scheme 2. Reaction between an organic radical and a metal complex leading to metal-carbon bond formation.

In recent years, the use of copper complexes with greater catalytic activity in ATRP, i.e. greater $K_{\text {ATRP }}$ (Scheme 1), ${ }^{16,17}$ was shown to promote competitive radical trapping by the $\mathrm{Cu} / \mathrm{L}$ ATRP catalyst with formation of the organometallic dormant species (i.e. sufficiently small $K_{\mathrm{OMRP}}$, Scheme 2). However, rather than helping the system to gain better control, this phenomenon opened access to a metal-catalyzed radical termination pathway, termed "catalytic radical termination" (CRT, Scheme 3). ${ }^{18-22}$ This process consists of a reaction between the organometallic intermediate $\mathrm{R}-\mathrm{Cu} / \mathrm{II} / \mathrm{L}$ and a second radical to yield termination products and regenerate the $\mathrm{Cu} / \mathrm{L}$ catalyst, and was found particularly prevalent when $\mathrm{R}^{\bullet}$ is a growing polyacrylate chain.

$$
\mathrm{R}-\mathrm{C} \mathrm{u}^{\prime \prime} / \mathrm{L}+\mathrm{R}^{\bullet} \stackrel{k_{\mathrm{CRT}}}{\longrightarrow} \mathrm{Cu}^{\prime} / \mathrm{L}+\text { termination products }\left\{\begin{array}{c}
\text { combination } \\
(\mathrm{R}-\mathrm{R}) \\
\text { or } \\
\text { disproportionation } \\
\left(\mathrm{R}-\mathrm{H}+\mathrm{R}^{(-\mathrm{H})}\right)
\end{array}\right.
$$

Scheme 3. Reaction between an organocopper(II) complex and a second radical, yielding radical termination and regenerating the copper(I) complex.

Investigations aimed at learning about the intimate mechanism of the CRT process have been recently conducted. In an initial study, ${ }^{19}$ well-defined bromine-capped polystyrene (PSt-Br) and poly(methyl acrylate) (PMA-Br) chains of known average molecular mass and low dispersity, prepared by ATRP, were activated by atom transfer to $\mathrm{Cu}$ Br/TPMA $(\mathrm{TPMA}=\operatorname{tris}(2-$ pyridylmethyl)amine, see Scheme 4) and the produced radicals were allowed to terminate in the absence of monomer. These studies were conducted in $\mathrm{MeCN}$ at $25^{\circ} \mathrm{C}$ with the activating system 
formed in situ from $\mathrm{Cu}^{\mathrm{I}} \mathrm{Br}$ and TPMA, while $\mathrm{Cu}^{\mathrm{II}} \mathrm{Br}_{2}$ was also present to moderate the activation equilibrium (Scheme 1). The PSt-Br activation was found to yield a double-molecular weight product, as expected from radical-radical coupling (combination). Since CRT is not efficient for these radicals, ${ }^{23}$ the latter mostly undergo non-catalyzed bimolecular termination, which occurs predominantly by combination. ${ }^{24}$ On the other hand, PMA-Br activation yielded a product with the same average molecular weight of the precursor, indicating the absence of combination. Since polyacrylate radicals are also known to terminate mostly by combination ${ }^{25,26}$ (although this view has recently been challenged ${ }^{27}$ ), this result was attributed to the copper-catalyzed termination (Scheme 3).

In a subsequent study, a PMA-Br sample was activated by $\mathrm{Cu}^{\mathrm{I}}$ systems made in situ from $\left[\mathrm{Cu}(\mathrm{MeCN})_{4}\right]^{+} \mathrm{OTf}^{-}$and three different ligands (TPMA*3, TPMA or $\mathrm{Me}_{6} \mathrm{TREN}$, Scheme 4), allowing termination reactions to occur in $\mathrm{MeCN}$ at $25^{\circ} \mathrm{C}$ in the absence of monomer. ${ }^{21}$ The recovered polymer had a bimodal distribution, the two components having respectively the same and a double average molecular weight relative to that of the macroinitiator. A key feature of this study was that the relative contribution of standard bimolecular (non-metal-mediated) radical termination (RT) and copper-catalyzed radical termination (CRT) was tuned by a change of the initial $\mathrm{Cu}^{\mathrm{I} / \mathrm{Cu}^{\mathrm{II}}}$ ratio. The observed trends and the accompanying kinetic simulation studies confirmed that RT yields nearly exclusively combination and suggested that the products with the same molar mass distribution as the macroinitiator originate from CRT. 


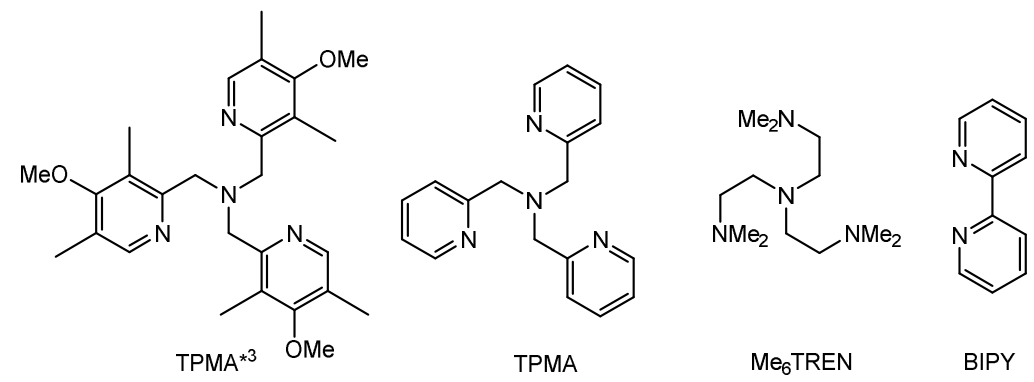

Scheme 4. Ligands used in this and previous studies.

A related investigation, ${ }^{28}$ however, revealed a new phenomenon. In that study, a PMA-Br macroinitiator of narrow molar mass distribution was again used and activated by $\mathrm{Cu}^{\mathrm{I} B r} / \mathrm{Me}_{6} \mathrm{TREN}$ in the absence of monomer. Two important differences relative to the investigations carried out in our laboratories were the use of (undried) toluene as solvent and metallic copper $\left(\mathrm{Cu}^{0}\right)$, which was added to the system rather than a $\mathrm{Cu}^{\mathrm{II}}$ salt. The resulting polymer had again a bimodal MWD, with the two contributing distributions having the same and double molecular weights, in agreement with our study. However, a detailed analysis of the recovered polymer by NMR and by mass spectrometry showed the absence of unsaturated chain, $\mathrm{PMA}^{(-\mathrm{H})}$. Rather, the distribution with the same average molar mass as the PMA-Br precursor contained only saturated chain ends, PMA-H, thus excluding that it was generated by radical disproportionation. Furthermore, an additional experiment carried out in the presence of $\mathrm{CH}_{3} \mathrm{OD}$ yielded the corresponding PMA-D while the double molecular weight distribution completely disappeared. The saturated chains were proposed by the authors to originate from protonolysis (by adventitious water in the medium or by the added methanol) of the organometallic intermediate. The reaction scheme is summarized in Scheme 5. 
(a)

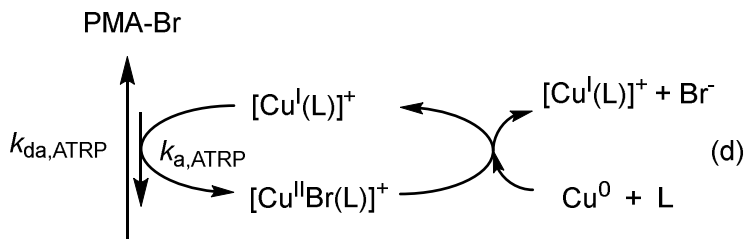

(c)

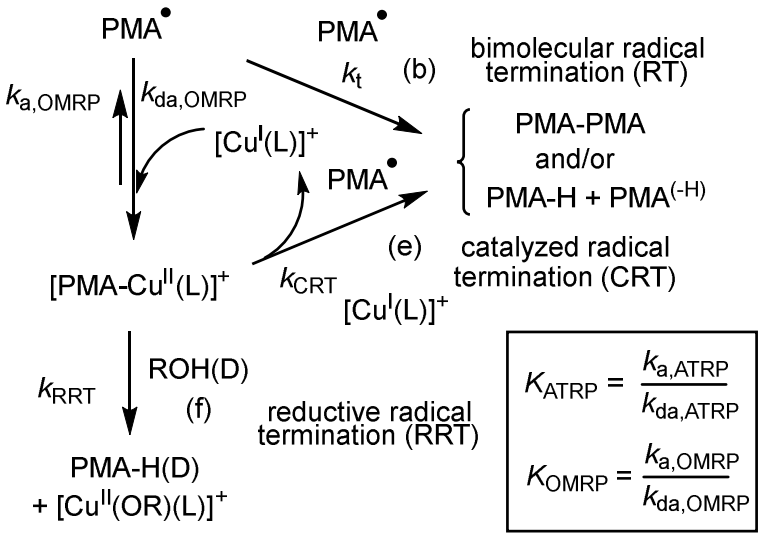

Scheme 5. Possible events in the copper-mediated termination of poly(methyl acrylate) radicals in the presence of methanol.

After activation of PMA-Br (a), the radicals can either terminate spontaneously in a bimolecular fashion according to (b) or be trapped by $\left[\mathrm{Cu}^{\mathrm{I}}(\mathrm{L})\right]^{+}$according to (c), while $\mathrm{Cu}^{0}$, if present together with additional $\mathrm{L}$, would convert the $\left[\mathrm{Cu}{ }^{\mathrm{II}} \mathrm{Br}(\mathrm{L})\right]^{+}$product back to $[\mathrm{Cu}(\mathrm{L})]^{+}$by comproportionation according to (d). Subsequently, the generated OMRP dormant species [PMA-Cu$\left.{ }^{\mathrm{II}}(\mathrm{L})\right]^{+}$may react with a second radical leading to CRT (e). Yamago et al. also proposed an alternative bimolecular CRT pathway involving interaction between two $\left[\mathrm{PMA}-\mathrm{Cu}{ }^{\mathrm{II}}(\mathrm{L})\right]^{+}$complexes. ${ }^{28}$ Competing with CRT, the $\left[\mathrm{PMA}-\mathrm{Cu}^{\mathrm{II}}(\mathrm{L})\right]^{+}$species may react with a proton donor to yield the observed PMA-H and a secondary $\mathrm{Cu}^{\mathrm{II}}$ complex, $\left[\mathrm{Cu}^{\mathrm{II}}(\mathrm{OR})(\mathrm{L})\right]^{+}$(f). We propose to name the latter process "Reductive Radical Termination" (RRT). It is a stoichiometric process, not a catalytic one, because it does not regenerate a $\mathrm{Cu}^{\mathrm{I}}$ complex. Incidentally, a recent report has also shown the ability of $\mathrm{Cu}^{0}$ to catalyzed acrylate radical termination, ${ }^{29}$ which is not included in Scheme 5. 
While there is no doubt about the existence of RRT and on the nature of the resulting product, the intimate mechanisms and the nature of the bimolecular terminations (RT and CRT) products are controversial. Yamago et al. have claimed that RT results in disproportionation ${ }^{27}$ and, since the unsaturated disproportionation product was not observed in the presence of the copper complex (even in the absence of proton donor), they proposed that RT (Scheme 5b) is totally suppressed by the faster OMRP trapping (c) and subsequent decompositions (e/f). ${ }^{28}$ Hence, for the experiment run in the absence of deliberately added methanol, they deduced that the distribution with average molar mass equivalent to that of PMA-Br (PMA-H) results from RRT, while the double molecular weight distribution (PMA-PMA) results from CRT and proposed that this product is generated by reductive elimination from a dialkylcopper intermediate. However, our own above-mentioned study carried out with variable $\mathrm{Cu}^{\mathrm{II}} / \mathrm{Cu}^{\mathrm{I}}$ ratios, run under very similar conditions to those of Yamago et al., gave essentially the same bimodal distribution and clearly demonstrated that the double molecular weight PMA-PMA product is generated by RT. ${ }^{21}$ Our reinterpretation of the results from the study by Yamago et al. is that the double molecular weight distribution observed at low $[\mathrm{ROH}]$ results from RT (Scheme 5b) and that an increasing concentration of the proton donor skews the product distribution in favor of RRT (Scheme 5, $\mathrm{c}+\mathrm{f}$ ). Complete suppression of $\mathrm{RT}$ is expected at high $[\mathrm{ROH}]$ because the $\mathrm{RRT}$ rate $\left(v_{\mathrm{RRT}}=K_{\mathrm{OMRP}} k_{\mathrm{RRT}}\left[\mathrm{Cu}^{\mathrm{I}}(\mathrm{L})^{+}\right]\left[\mathrm{PMA}^{\bullet}\right][\mathrm{ROH}]\right)$ would become dominant relative to that of RT $\left(v_{\mathrm{t}}=k_{\mathrm{t}}\left[\mathrm{PMA}^{*}\right]^{2}\right)$. At low $[\mathrm{ROH}]$, even though OMRP trapping (Scheme $5 \mathrm{c}, k_{\mathrm{da}, \mathrm{OMRP}}\left[\mathrm{Cu}^{\mathrm{I}}(\mathrm{L})^{+}\right]\left[\mathrm{PMA}^{*}\right]$ ) can compete with $\mathrm{RT}$, the reversibility of the former allows RT and CRT to remain in competition.

One specific result of the contribution by Yamago et al. ${ }^{28}$ however, requires further analysis. In the absence of any added $\mathrm{CH}_{3} \mathrm{OH}(\mathrm{D})$, unsaturated chains expected from disproportionation were still absent in the lower molecular weight fraction, ruling out any pathway leading to 
disproportionation products. While the double molecular weight distribution (PMA-PMA) may result from either RT (according to us) ${ }^{21}$ or from CRT (according to Yamago et al.), ${ }^{28}$ the selective production of PMA-H in the absence of $\mathrm{ROH}$ is puzzling. Yamago et al. attributed this phenomenon to the efficient OMRP trapping (Scheme $5 \mathrm{c}$ ) followed by RRT as a consequence of the water impurities in the solvent. Another interesting question is whether the RRT pathway occurs via an organometallic species. Indeed, this termination process may also occur by outersphere or inner-sphere electron transfer processes, coupled with protonation, as shown in Scheme 6. On the left, the organometallic pathway already considered in Scheme 5 is represented, which we name OMRP because it involves the dormant species of an organometallic-mediated radical polymerization. In the middle, the scheme shows a termolecular outer-sphere proton-coupled electron transfer (OS-PCET). Finally, the right hand side shows the two-step process involving initial coordination of the proton donor to the $\left[\mathrm{Cu}^{\mathrm{I}}(\mathrm{L})\right]^{+}$complex, followed by proton-coupled electron transfer, which we name inner-sphere PCET, or IS-PCET. The involvement of metal complexes to mediate PCET is well established ${ }^{30}$ and an IS-PCET process was found kinetically competent in a recent mechanistic study of $\mathrm{Fe}(\mathrm{acac})_{3}$-catalyzed radical alkene cross-coupling. ${ }^{31}$

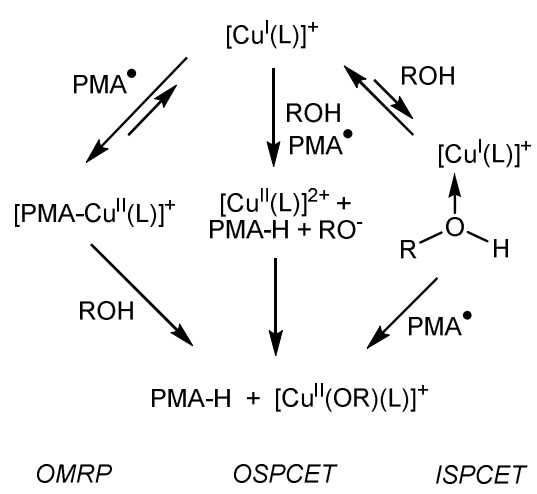

Scheme 6. Possible pathways for reductive radical termination. 
It is also relevant to mention the seminal work of Meyerstein, who has investigated the interaction between organic radicals and transition metal complexes, including those of $\mathrm{Cu}^{\mathrm{I}}$, carrying out their studies in water or aqueous media. ${ }^{32-44}$ The resulting organocopper transients usually decomposed by protonolysis. ${ }^{45}$ Those investigations, however, did not pay particular attention to the competition between trapping by $\mathrm{Cu}^{\mathrm{I}}$ and spontaneous bimolecular termination and have mostly dealt with relatively reactive (non-stabilized) radicals, which have a strong tendency to generate organocopper(II) species. Exceptions are ${ }^{\circ} \mathrm{CH}_{2} \mathrm{COOH}$ and ${ }^{\circ} \mathrm{CH}_{2} \mathrm{COO}^{-}$, 43 where the unpaired electron is stabilized by delocalization onto the carboxylic function. The neutral ${ }^{\circ} \mathrm{CH}_{2} \mathrm{COOH}$ radical gives the organocopper(II) adduct with $\mathrm{Cu}^{+}{ }_{\text {aq }}$ at a rate comparable to those of the more reactive radicals ${ }^{\circ} \mathrm{CH}_{3}$ and ${ }^{\circ} \mathrm{CH}_{2} \mathrm{CH}_{2} \mathrm{COOH}\left(>10^{9} \mathrm{M}^{-1} \mathrm{~s}^{-1}\right)$, whereas the anionic ${ }^{\circ} \mathrm{CH}_{2} \mathrm{COO}^{-}$radical adds one order of magnitude slower than ${ }^{\circ} \mathrm{CH}_{3}$ to a $[\mathrm{Cu}(\mathrm{L})]^{+}$complex $(\mathrm{L}=$ 2,5,8,11-tetramethyl-2,5,8,11-tetraazadodecane), but still formed an organocopper(II) transient. The decomposition of the $\left[\mathrm{Cu}^{\mathrm{II}}-\mathrm{CH}_{2} \mathrm{COOH}\right]^{+}{ }_{\text {aq }}$ and $\left[(\mathrm{L}) \mathrm{Cu}^{\mathrm{II}}-\mathrm{CH}_{2} \mathrm{COO}\right]$ transients was found to occur by protonolysis to yield $\mathrm{CH}_{3} \mathrm{COOH}$ or $\mathrm{CH}_{3} \mathrm{COO}^{-}$and $\mathrm{Cu}^{2+}{ }_{\text {aq }}$ or $\left[\mathrm{Cu}^{\mathrm{II}}(\mathrm{L})\right]^{2+}$, respectively.

In order to learn more about the RRT mechanism and about its impact in an ATRP/OMRP system, we have embarked in a detailed investigation of the nature of the termination products for stabilized radicals interacting with a variety of $\mathrm{Cu}^{\mathrm{I}}$ complexes in non-aqueous solvents and in the presence of controlled amounts of proton donors. The interaction between carbon-based radicals and copper complexes in non-aqueous solvents is a relatively unexplored area of investigations. ${ }^{45}$ The guiding principle is to probe radicals with a greater or smaller aptitude to generate an organometallic intermediate (thus probing the OMRP pathway in Scheme 6 relative to the other possible PCET pathways). In this report, we focus on the stabilized cyanoisopropyl radical 
$\left(\mathrm{Me}_{2}(\mathrm{CN}) \mathrm{C}^{*}\right)$, with the idea in mind that this radical may be unable to generate an organocopper(II) intermediate because of an insufficiently strong $\mathrm{Cu}^{\mathrm{II}}-\mathrm{C}$ bond.

\section{Experimental section}

Material and methods. Copper(I) bromide (CuBr, Sigma-Aldrich, 99.8\%), copper(0) powder (<425 $\mu \mathrm{m}$, Sigma-Aldrich, 99.5\%), tris[2-(dimethylamino)ethyl]amine (Me 6 TREN, Alfa Aesar, 99\%), tris(2-pyridylmethyl)amine (TPMA, AmBeed or Koei Chemical Co. Ltd, 98\%) and 2,2'bipyridine (BIPY, Sigma-Aldrich, 99\%) were used as received without any purification. 2,2'Azobis(isobutyronitrile) (AIBN, Sigma-Aldrich, 98\%) was recrystallized from methylene chloride at $-32^{\circ} \mathrm{C}$. Tetrakis(acetonitrile)copper(I) tetrafluoroborate $\left(\left[\mathrm{Cu}(\mathrm{MeCN})_{4}\right] \mathrm{BF}_{4}\right.$, Acros Organics, 99\%) was recrystallized from $\mathrm{MeCN}$. Anhydrous deuterated acetonitrile $\left(\mathrm{CD}_{3} \mathrm{CN}\right.$, Eurisotop, 99.8\% D) was distilled over $\mathrm{CaH}_{2}$ under an inert atmosphere and stored in a sealed flask. Anhydrous deuterated benzene $\left(\mathrm{C}_{6} \mathrm{D}_{6}\right.$, Eurisotop, $\left.99.5 \% \mathrm{D}\right)$ was distilled over $\mathrm{NaK}$ alloy under an inert atmosphere and stored in a sealed flask. Methanol (MeOH, Carlo Erba, analytical grade) and deuterated methanol ( $\mathrm{CD}_{3} \mathrm{OD}$, Eurisotop, $\left.99.9 \% \mathrm{D}\right)$ were dried over activated $4 \AA ̊$ molecular sieves and stored under an inert atmosphere in a sealed flask. Triethylammonium tetrafluoroborate ([Et $3 \mathrm{NH}]\left[\mathrm{BF}_{4}\right]$ was synthesized according to the literature. ${ }^{46}$ The ${ }^{1} \mathrm{H}$ NMR spectra were recorded on a Bruker Avance III 300 or $400 \mathrm{MHz}$ spectrometer at ambient temperature; chemical shifts $(\delta)$ are reported in ppm vs. $\mathrm{SiMe}_{4}$ and were determined by reference to the residual ${ }^{1} \mathrm{H}$ solvent peaks. The coupling constants are reported in Hertz.

General procedure for the $\mathrm{AIBN}$ termination in $\mathbf{C D}_{3} \mathrm{CN}$. A degassed solution of $\mathrm{CD}_{3} \mathrm{CN}$ containing the ligand $\left(8.6 \cdot 10^{-2} \mathrm{mmol}, 2\right.$ eq relative to $\left.\mathrm{Cu}\right)$ and AIBN $\left(3.6 \mathrm{mg}, 2.1 \cdot 10^{-2} \mathrm{mmol}, 0.5\right.$ eq relative to $\mathrm{Cu}$ ) was transferred via cannula to a screw-capped NMR tube containing 
$\left[\mathrm{Cu}(\mathrm{MeCN})_{4}\right]^{+} \mathrm{BF}_{4}^{-}\left(13.5 \mathrm{mg}, 4.3 \cdot 10^{-2} \mathrm{mmol}\right)$. The solution was heated at $80^{\circ} \mathrm{C}$ for $8 \mathrm{~h}$, then cooled to room temperature and analyzed by ${ }^{1} \mathrm{H}$ NMR spectroscopy.

General procedure for the $\mathbf{A I B N}$ termination in $\mathbf{C}_{6} \mathbf{D}_{6}$. A degassed solution of $\mathrm{C}_{6} \mathrm{D}_{6}$ containing the ligand $\left(8.6 \cdot 10^{-2} \mathrm{mmol}, 1.7\right.$ eq relative to $\left.\mathrm{Cu}^{\mathrm{I}}\right)$ and $\mathrm{AIBN}\left(8.2 \mathrm{mg}, 5.1 \cdot 10^{-2} \mathrm{mmol}, 1\right.$ eq relative to $\left.\mathrm{Cu}^{\mathrm{I}}\right)$ was transferred via cannula to a screw-capped NMR tube containing $\mathrm{CuBr}(7.3$ $\left.\mathrm{mg}, 5.1 \cdot 10^{-2} \mathrm{mmol}\right)$ and $\mathrm{Cu}^{0}\left(12 \mathrm{mg}, 20.4 \cdot 10^{-2} \mathrm{mmol}, 4\right.$ eq relative to $\left.\mathrm{Cu}^{\mathrm{I}}\right)$. The solution was heated at $75^{\circ} \mathrm{C}$ for $8 \mathrm{~h}$, then cooled to room temperature and analyzed by ${ }^{1} \mathrm{H}$ NMR spectroscopy.

Computational details. The DFT calculations were carried out using the Gaussian09 suite of programs. ${ }^{47}$ Geometry optimizations were performed for the isolated molecules without any symmetry constraint using the BP86 functional ${ }^{48}$ and the $6-311 \mathrm{G}(\mathrm{d}, \mathrm{p})$ basis functions for all the light atoms $(\mathrm{O}, \mathrm{N}, \mathrm{C}, \mathrm{H})$ and the LANL2DZ functions for $\mathrm{Cu}$, to which was added an $f$ polarization function $(\alpha=3.325 \mathrm{Cu}){ }^{49}$ The unrestricted formulation was used for open-shell spin doublets, yielding only minor spin contamination $\left(<\mathrm{S}^{2}\right\rangle$ at convergence was very close to the expected value of 0.75 , the maximum deviation being 0.758 for the free cyanoisopropyl radical, $\left.\left(\mathrm{CH}_{3}\right)_{2}(\mathrm{CN}) \mathrm{C}^{*}\right)$. All final geometries were characterized as local minima by verifying that all second derivatives of the energy were positive. Thermochemical corrections were obtained at $298.15 \mathrm{~K}$ on the basis of frequency calculations, using the standard approximations (ideal gas, rigid rotor and harmonic oscillator). Corrections for dispersion were carried out at the fixed BP86 optimized geometries using Grimme's D3 empirical method (BP86-D3), using S6 = 1, SR6 = 1.1390 and S8 $=1.6830 .{ }^{50}$ A solvation correction in acetonitrile $(\varepsilon=35.688)$ was carried out using the SMD polarizable continuum model. ${ }^{51}$ A further correction of $1.95 \mathrm{Kcal} / \mathrm{mol}$ was applied to bring the $\mathrm{G}$ values from the gas phase $(1 \mathrm{~atm})$ to the solution $(1 \mathrm{~mol} / \mathrm{L})$ standard state. ${ }^{52}$ 


\section{Results and Discussion}

\section{(a) Control experiments}

The cyanoisopropyl radical was conveniently generated by thermal decomposition of azobis(isobutyronitrile) ( $\left.\mathrm{AIBN} ; \mathrm{Me}_{2} \mathrm{C}(\mathrm{CN})-\mathrm{N}=\mathrm{N}-\mathrm{C}(\mathrm{CN}) \mathrm{Me}_{2}\right)$ in either $\mathrm{CD}_{3} \mathrm{CN}$ or $\mathrm{C}_{6} \mathrm{D}_{6}$ and the nature and amount of the formed products were determined by ${ }^{1} \mathrm{H}$ NMR integration (see SI, section S1). All decomposition experiments in $\mathrm{CD}_{3} \mathrm{CN}$ were conducted, unless otherwise stated, at $80^{\circ} \mathrm{C}$ (where the half-life is reported as ca. 70 min or $1.2 \mathrm{~h}$ ) for $8 \mathrm{~h}$, whereas all those in $\mathrm{C}_{6} \mathrm{D}_{6}$ were set at $75^{\circ} \mathrm{C}\left(t_{1 / 2}=\right.$ ca. $150 \mathrm{~min}$ or $\left.2.5 \mathrm{~h}\right)$, also for $8 \mathrm{~h}$. The observed fraction of decomposed AIBN is consistent with the reported decomposition rates in the presence of $\mathrm{Cu}^{\mathrm{I}}$ complexes, ${ }^{53}$ with some variability caused by the imperfect control of the heating bath temperature and/or occasional induction periods because of oxygen contamination. The product distributions reported in all tables below are relative to the converted AIBN fraction. Control experiments conducted in the absence of both copper complex and proton donor (Table 1, entries 1 and 2) yield mainly tetramethylsuccinonitrile, $\mathrm{Me}_{2} \mathrm{C}(\mathrm{CN})-\mathrm{C}(\mathrm{CN}) \mathrm{Me}_{2}$ (indicated as 'dimer') and a minor amount of isobutyronitrile (iBN) as secondary product (Scheme 7). This is in line with a previous investigation ${ }^{54}$ and with the known termination mode in the polymerization of acrylonitrile and methacrylonitrile, which occurs predominantly by combination. ${ }^{55}$ The observed iBN probably derives from a small amount of disproportionation, but the expected methacylonitrile co-product was not observed in this specific control experiment, because it is subsequently consumed by radical addition with formation of oligomers as previously demonstrated ${ }^{54}$ Small amounts of vinyl protons were indeed occasionally observed in the ${ }^{1} \mathrm{H}$ NMR spectra for other experiments during the investigation. Since the putative oligomers could not be quantified, the percent of coupling and saturated product reported in Table 1 cannot be taken as precise measures of the percent coupling 
and disproportionation for the cyanoisopropyl radical. The observed dimer/iBN product ratio was about the same (ca. 10:1) in both $\mathrm{CD}_{3} \mathrm{CN}$ and $\mathrm{C}_{6} \mathrm{D}_{6}$. Additional control experiments were carried out in the presence of proton donors, still in the absence of any copper complex. Both water and methanol (regular or deuterated) were used in $\mathrm{CD}_{3} \mathrm{CN}$, whereas only methanol could be used in $\mathrm{C}_{6} \mathrm{D}_{6}$ for miscibility reasons. The results (entries 3-6 in $\mathrm{CD}_{3} \mathrm{CN}$, entries 7 and 8 in $\mathrm{C}_{6} \mathrm{D}_{6}$ ) do not greatly differ from those obtained in the absence of these proton-donor additives. The only slight difference was the detection of minor amounts of isobutyramide, $\mathrm{Me}_{2} \mathrm{CHONH}_{2}$, resulting from hydrolysis of the isobutyronitrile, for the experiments carried out in the presence of water.

Table 1. Results of the thermal decomposition of AIBN in the absence of copper complexes. ${ }^{\mathrm{a}}$

\begin{tabular}{|l|l|l|l|l|}
\hline Entry & Solvent & Additive/AIBN & iBN/dimer ${ }^{\mathrm{b}}$ & $\% \mathrm{D}^{\mathrm{c}}$ \\
\hline 1 & $\mathrm{CD}_{3} \mathrm{CN}$ & - & 0.11 & \\
\hline 2 & $\mathrm{C}_{6} \mathrm{D}_{6}$ & - & 0.07 & \\
\hline 3 & $\mathrm{CD}_{3} \mathrm{CN}$ & $\mathrm{H}_{2} \mathrm{O}(200)$ & $0.11^{\mathrm{d}}$ & \\
\hline 4 & $\mathrm{CD}_{3} \mathrm{CN}$ & $\mathrm{D}_{2} \mathrm{O}(200)$ & $0.11^{\mathrm{d}}$ & n.d. \\
\hline 5 & $\mathrm{CD}_{3} \mathrm{CN}$ & $\mathrm{CH}_{3} \mathrm{OH}(40)$ & 0.12 & \\
\hline 6 & $\mathrm{CD}_{3} \mathrm{CN}$ & $\mathrm{CD}_{3} \mathrm{OD}(40)$ & 0.13 & n.d. \\
\hline 7 & $\mathrm{C}_{6} \mathrm{D}_{6}$ & $\mathrm{CH}_{3} \mathrm{OH}(200)$ & 0.08 & \\
\hline 8 & $\mathrm{C}_{6} \mathrm{D}_{6}$ & $\mathrm{CD}_{3} \mathrm{OD}(200)$ & 0.09 & n.d. \\
\hline
\end{tabular}

${ }^{\mathrm{a}}$ Experiments in $\mathrm{CD}_{3} \mathrm{CN}: \mathrm{T}=80^{\circ} \mathrm{C}, 8 \mathrm{~h}$; experiments in $\mathrm{C}_{6} \mathrm{D}_{6}: \mathrm{T}=75^{\circ} \mathrm{C}, 8 \mathrm{~h} .{ }^{\mathrm{b}}$ Ratio of the two $\mathrm{Me}_{2} \mathrm{C}$ resonances (see SI), hence equivalent to the moral ratio of AIBN leading to each product. ${ }^{c}$ n.d. = not detectable (the integral of the two peaks of the $\mathrm{iBN}(\mathrm{H})$ doublet are identical within experimental error). ${ }^{\mathrm{d}} \mathrm{A}$ small amount of amide $\left(\mathrm{Me}_{2} \mathrm{CHCONH}_{2}\right.$ or $\left.\mathrm{Me}_{2} \mathrm{CHCOND}_{2},<1 \%\right)$ was also detected. 


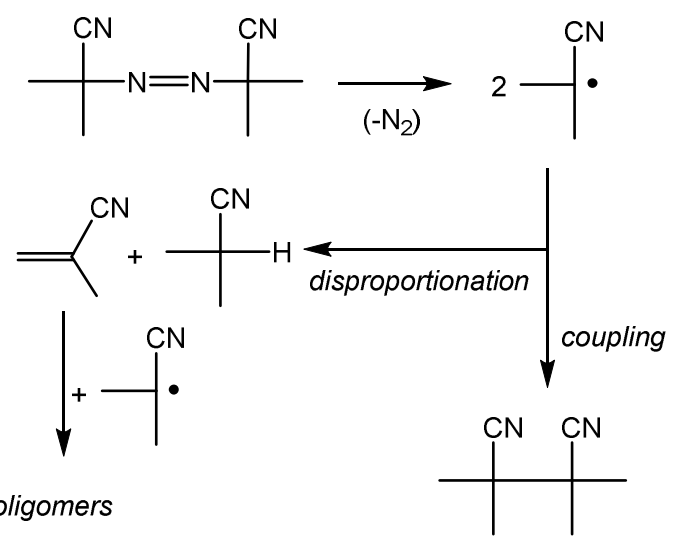

Scheme 7. AIBN decomposition in the absence of $\mathrm{Cu}^{\mathrm{I}}$ complex.

\section{(b) Decomposition in the presence of $\mathrm{Cu}^{\mathrm{I}}$ complexes with $\mathrm{Me}_{6}$ TREN}

The $\mathrm{Me}_{6}$ TREN ligand was selected for the initial studies in the presence of $\mathrm{Cu}^{\mathrm{I}}$ (Table 2). Termination experiments were first carried out without any proton donor additive (entries 9 and 10 in $\mathrm{CD}_{3} \mathrm{CN}$ and $\mathrm{C}_{6} \mathrm{D}_{6}$, respectively). The results, in both solvents, are again quite similar to those obtained in the absence of copper complex, showing that the presence of the complex alone does not significantly affect the radical decomposition mode. A marginal increase of the iBN production in $\mathrm{CD}_{3} \mathrm{CN}$ may result from the presence of small amounts of water in the deuterated solvent (which was found to be ca 0.05 equiv relative to AIBN by ${ }^{1} \mathrm{H}$ NMR integration), but the difference is barely significant. The deuterated benzene is much drier - no detectable $\mathrm{H}_{2} \mathrm{O}$ by ${ }^{1} \mathrm{H} \mathrm{NMR}-$ and the results (entry 10) are essentially identical to those of the control in entry 2 (Table 1). An additional control experiment run in $\mathrm{C}_{6} \mathrm{D}_{6}$ that had been dried and distilled over $\mathrm{Na} / \mathrm{K}$ (entry 11 ) gave a marginally lower iBN/dimer ratio.

Table 2. Results of the thermal decomposition of AIBN in the presence of the $\mathrm{Cu}^{\mathrm{I}} / \mathrm{Me}_{6} \mathrm{TREN}$ system. $^{\mathrm{a}}$

\begin{tabular}{|l|l|l|l|l|l|}
\hline Entry & Solvent & $\mathrm{Cu}^{\mathrm{I}}$ complex & Additive/AIBN & iBN/dimer $^{\mathrm{b}}$ & $\% \mathrm{D}_{\text {in }} \mathrm{iBN}^{\mathrm{c}}$ \\
\hline
\end{tabular}




\begin{tabular}{|c|c|c|c|c|c|}
\hline 9 & $\mathrm{CD}_{3} \mathrm{CN}$ & {$\left[\mathrm{Cu}^{\mathrm{I}}\left(\mathrm{Me}_{6} \mathrm{TREN}\right)\right]^{+} \mathrm{BF}_{4}^{-}$} & - & 0.16 & \\
\hline 10 & $\mathrm{C}_{6} \mathrm{D}_{6}$ & $\mathrm{CuBr} / \mathrm{Me}_{6} \mathrm{TREN}$ & - & 0.09 & \\
\hline $11^{\mathrm{d}}$ & $\mathrm{C}_{6} \mathrm{D}_{6}$ & $\mathrm{CuBr} / \mathrm{Me}_{6} \mathrm{TREN}$ & - & 0.06 & \\
\hline 12 & $\mathrm{CD}_{3} \mathrm{CN}$ & {$\left[\mathrm{Cu}^{\mathrm{I}}\left(\mathrm{Me}_{6} \mathrm{TREN}\right)\right]^{+} \mathrm{BF}_{4}^{-}$} & $\mathrm{H}_{2} \mathrm{O}(200)$ & $4.28^{\mathrm{e}}$ & \\
\hline 13 & $\mathrm{CD}_{3} \mathrm{CN}$ & {$\left[\mathrm{Cu}^{\mathrm{I}}\left(\mathrm{Me}_{6} \mathrm{TREN}\right)\right]^{+} \mathrm{BF}_{4}^{-}$} & $\mathrm{D}_{2} \mathrm{O}(200)$ & 1.09 & 85.0 \\
\hline 14 & $\mathrm{CD}_{3} \mathrm{CN}$ & {$\left[\mathrm{Cu}^{\mathrm{I}}\left(\mathrm{Me}_{6} \mathrm{TREN}\right)\right]^{+} \mathrm{BF}_{4}^{-}$} & $\mathrm{CH}_{3} \mathrm{OH}(2)$ & 0.20 & \\
\hline 15 & $\mathrm{CD}_{3} \mathrm{CN}$ & {$\left[\mathrm{Cu}^{\mathrm{I}}\left(\mathrm{Me}_{6} \mathrm{TREN}\right)\right]^{+} \mathrm{BF}_{4}^{-}$} & $\mathrm{CH}_{3} \mathrm{OH}(40)$ & 1.65 & \\
\hline 16 & $\mathrm{CD}_{3} \mathrm{CN}$ & {$\left[\mathrm{Cu}^{\mathrm{I}}\left(\mathrm{Me}_{6} \mathrm{TREN}\right)\right]^{+} \mathrm{BF}_{4}^{-}$} & $\mathrm{CH}_{3} \mathrm{OH}(200)$ & 3.17 & \\
\hline 17 & $\mathrm{CD}_{3} \mathrm{CN}$ & {$\left[\mathrm{Cu}^{\mathrm{I}}\left(\mathrm{Me}_{6} \mathrm{TREN}\right)\right]^{+} \mathrm{BF}_{4}^{-}$} & $\mathrm{CD}_{3} \mathrm{OD}(2)$ & 0.23 & 17.2 \\
\hline 18 & $\mathrm{CD}_{3} \mathrm{CN}$ & {$\left[\mathrm{Cu}^{\mathrm{I}}\left(\mathrm{Me}_{6} \mathrm{TREN}\right)\right]^{+} \mathrm{BF}_{4}^{-}$} & $\mathrm{CD}_{3} \mathrm{OD}(40)$ & 0.15 & 13.8 \\
\hline 19 & $\mathrm{CD}_{3} \mathrm{CN}$ & {$\left[\mathrm{Cu}^{\mathrm{I}}\left(\mathrm{Me}_{6} \mathrm{TREN}\right)\right]^{+} \mathrm{BF}_{4}^{-}$} & $\mathrm{CD}_{3} \mathrm{OD}(200)$ & $0.94^{\mathrm{e}}$ & 65.3 \\
\hline 20 & $\mathrm{C}_{6} \mathrm{D}_{6}$ & $\mathrm{CuBr} / \mathrm{Me}_{6} \mathrm{TREN}$ & $\mathrm{CH}_{3} \mathrm{OH}(20)$ & 1.78 & \\
\hline 21 & $\mathrm{C}_{6} \mathrm{D}_{6}$ & $\mathrm{CuBr} / \mathrm{Me}_{6} \mathrm{TREN}$ & $\mathrm{CH}_{3} \mathrm{OH}(100)$ & 8.64 & \\
\hline $22^{d}$ & $\mathrm{C}_{6} \mathrm{D}_{6}$ & $\mathrm{CuBr} / \mathrm{Me}_{6} \mathrm{TREN}$ & $\mathrm{CH}_{3} \mathrm{OH}(100)$ & 7.81 & \\
\hline 23 & $\mathrm{C}_{6} \mathrm{D}_{6}$ & $\mathrm{CuBr} / \mathrm{Me}_{6} \mathrm{TREN}$ & $\mathrm{CD}_{3} \mathrm{OD}(20)$ & 0.35 & 54.7 \\
\hline 24 & $\mathrm{C}_{6} \mathrm{D}_{6}$ & $\mathrm{CuBr} / \mathrm{Me}_{6} \mathrm{TREN}$ & $\mathrm{CD}_{3} \mathrm{OD}(100)$ & 3.30 & 68.7 \\
\hline $25^{d}$ & $\mathrm{C}_{6} \mathrm{D}_{6}$ & $\mathrm{CuBr} / \mathrm{Me}_{6} \mathrm{TREN}$ & $\mathrm{CD}_{3} \mathrm{OD}(100)$ & 4.36 & 68.9 \\
\hline
\end{tabular}

${ }^{\mathrm{a}}$ Experiments in $\mathrm{CD}_{3} \mathrm{CN}$ : $\left[\mathrm{Cu}^{\mathrm{I}}(\mathrm{MeCN})_{4}\right] \mathrm{BF}_{4} / \mathrm{Me}_{6} \mathrm{TREN} / \mathrm{AIBN}=1: 2: 0.5, \mathrm{~T}=80^{\circ} \mathrm{C}, 8 \mathrm{~h}$; experiments in $\mathrm{C}_{6} \mathrm{D}_{6}:[\mathrm{CuBr}] / \mathrm{Cu}^{0} / \mathrm{Me}_{6} \mathrm{TREN} / \mathrm{AIBN}=1: 4: 1.7: 1, \mathrm{~T}=75^{\circ} \mathrm{C}, 8 \mathrm{~h}$ (unless otherwise stated). ${ }^{\mathrm{b}}$ Ratio of the two $\mathrm{Me}_{2} \mathrm{C}$ resonances (see SI), hence equivalent to the moral ratio of AIBN leading to each product. ${ }^{\mathrm{c}}$ Fraction of $\mathrm{Me}_{2} \mathrm{CD}(\mathrm{CN})$ in the $\mathrm{iBN}$ product, determined by ${ }^{1} \mathrm{H} \mathrm{NMR}$ integration. ${ }^{\mathrm{d}}$ Thermal decomposition for $24 \mathrm{~h}$ in $\mathrm{C}_{6} \mathrm{D}_{6}$ that was dried and distilled over $\mathrm{Na} / \mathrm{K} .{ }^{\mathrm{e}} \mathrm{A}$ small amount of amide $\left(\mathrm{Me}_{2} \mathrm{CHCONH}_{2}\right.$ or $\left.\mathrm{Me}_{2} \mathrm{CHCOND}_{2},<1 \%\right)$ was also detected.

The deliberate addition of 200 equiv of water (relative to AIBN, or 100 equiv. relative to the $\mathrm{Cu}$ complex) in MeCN dramatically changed the product distribution in favor of iBN (Table 2, entry 12). Replacement of water with the same amount of $\mathrm{D}_{2} \mathrm{O}$ (entry 13) yielded a lower amount of iBN relative to entry 12 , but still much greater than in the control experiment of entry 9 , and nearly $90 \%$ of this product was deuterated $\left(\mathrm{Me}_{2} \mathrm{CD}(\mathrm{CN})\right)$. The relative amount of this product could be rather precisely determined by ${ }^{1} \mathrm{H}$ NMR integration of the Me proton resonances (1:1:1 triplet for 
the deuterated product, vs. doublet for the non-deuterated compound, see section S1 in the SI). The dimer/iBN difference for $\mathrm{H}_{2} \mathrm{O}$ and $\mathrm{D}_{2} \mathrm{O}$ may be attributed to a kinetic isotope effect (KIE) in the reaction leading to the $\mathrm{iBN}$ product, while the imperfect deuteration of $\mathrm{iBN}$ may be attributed to the incorporation of the residual $\mathrm{H}$ in $\mathrm{D}_{2} \mathrm{O}$, plus the $\mathrm{H}_{2} \mathrm{O}$ originally present in the $\mathrm{CD}_{3} \mathrm{CN}$ solvent, in the presence of the KIE bias.

Use of regular and deuterated methanol (entries 14-16 and 17-19, respectively) as a proton donor gave the same trends. In this case, a finer study as a function of proton donor concentration was carried out, showing that the iBN/dimer ratio increases with the methanol/AIBN ratio. This ratio is greater with $\mathrm{CH}_{3} \mathrm{OH}$ than with $\mathrm{CD}_{3} \mathrm{OD}$ under identical conditions, again consistent with the presence of a KIE. It is however smaller than with the same amount of water ( $c f$. entries 16 and 12 , or 19 and 13). This shows that water is slightly more effective than methanol for generating the reduced iBN product. The observed deuterium incorporation was smaller with $\mathrm{CD}_{3} \mathrm{OD}$ than with $\mathrm{D}_{2} \mathrm{O}$, reflecting a greater impact of the residual $\mathrm{H}$ in the deuterated reagent or in the solvent. The same trends are also found for the experiments run with the $\mathrm{Cu}{ }^{\mathrm{I}} \mathrm{Br} / \mathrm{Cu}^{0} / \mathrm{Me}_{6} \mathrm{TREN} / \mathrm{methanol}$ combination in $\mathrm{C}_{6} \mathrm{D}_{6}$ (entries $20-25$ in Table 2). There is again a greater fraction of iBN with an increased amount of proton donor, and the $\mathrm{iBN}$ fraction is greater with $\mathrm{CH}_{3} \mathrm{OH}$ than with $\mathrm{CD}_{3} \mathrm{OD}$. In order to tell whether the residual $\mathrm{H}$ in $\mathrm{iBN}$ originates from the $\mathrm{CD}_{3} \mathrm{OD}$ reagent or from the solvent, the experiments were repeated with dried $\mathrm{C}_{6} \mathrm{D}_{6}$ (entries 22 and 25). The results, particularly the percent $\mathrm{D}$ incorporation in iBN, are essentially identical to those obtain in untreated $\mathrm{C}_{6} \mathrm{D}_{6}$, pointing to the $\mathrm{CD}_{3} \mathrm{OD}$ reagent as the most probable $\mathrm{H}$ source.

A comparison of the results obtained in the two different solvents shows that a greater iBN fraction was obtained in $\mathrm{C}_{6} \mathrm{D}_{6}$ (for instance, $c f$. entries 21 and 16, or 24 and 19), even though with a lower methanol/AIBN ratio. It is notable, however, that small amounts of the radical-radical 
coupling product (dimer) were always present, even when using 100 equivalents of $\mathrm{CH}_{3} \mathrm{OH}$. This result is in stark contrast with the results reported by Yamago et al. ${ }^{28}$ where the PMA ${ }^{\bullet}$ radicals produced by PMA-Br activation where fully quenched to $\mathrm{PMA}-\mathrm{H}$ by $\mathrm{Cu}^{\mathrm{I}}$ in the presence of only 10 equivalents of $\mathrm{CH}_{3} \mathrm{OH}$ or $\mathrm{CD}_{3} \mathrm{OD}$, with no visible detection of coupling product.

If RRT takes place according to the OMRP pathway (Scheme 6) the greater iBN fraction in $\mathrm{C}_{6} \mathrm{D}_{6}$ relative to $\mathrm{CD}_{3} \mathrm{CN}$ may be attributed to either a more favorable formation of the organometallic intermediate or to the greater acidity of the proton donor in this solvent, or to a contribution of both factors. The first hypothesis requires that a coordination site for the radical addition is more easily available in $\mathrm{C}_{6} \mathrm{D}_{6}$. The $\mathrm{Cu}^{\mathrm{I}}$ complex in this solvent is likely to be pentacoordinated, $\left[\mathrm{CuBr}\left(\kappa^{4}-\mathrm{Me}_{6} \mathrm{TREN}\right)\right]$, like the crystallographically characterized related $\left[\mathrm{CuBr}\left(\kappa^{4}-\mathrm{TPMA}\right)\right]^{56}$ and the resulting organocopper(II) adduct is also likely to adopt a 5-coordinated structure. Thus, the radical addition requires either dissociation of the bromide ion, $\left[\mathrm{Cu}\left\{\mathrm{C}(\mathrm{CN}) \mathrm{Me}_{2}\right\}\left(\kappa^{4}-\right.\right.$ $\left.\mathrm{Me}_{6} \mathrm{TREN}\right]^{+} \mathrm{Br}^{-}$, which is unlikely in a non-polar solvent, or dissociation of one of the $\mathrm{Me}_{6} \mathrm{TREN}$ $\mathrm{N}$ donor atoms, $\left[\mathrm{CuBr}\left\{\mathrm{C}(\mathrm{CN}) \mathrm{Me}_{2}\right\}\left(\kappa^{3}-\mathrm{Me}_{6} \mathrm{TREN}\right)\right]$. On the other hand, in $\mathrm{CD}_{3} \mathrm{CN}$ the $\mathrm{Cu}^{\mathrm{I}}$ complex may be either tetracoordinated, $\left[\mathrm{Cu}\left(\kappa^{4}-\mathrm{Me}_{6} \mathrm{TREN}\right)\right]^{+} \mathrm{BF}_{4}^{-}$, or pentacoordinated as a solvent adduct, $\left[\mathrm{Cu}\left(\kappa^{4}-\mathrm{Me}_{6} \mathrm{TREN}\right)\left(\mathrm{CD}_{3} \mathrm{CN}\right)\right]^{+} \mathrm{BF}_{4}^{-}$, like the related crystallographically characterized $\left[\mathrm{Cu}\left(\kappa^{4}-\mathrm{TPMA}\right)\left(\mathrm{CH}_{3} \mathrm{CN}\right)\right]^{+} \mathrm{BPh}_{4}{ }^{-57} \mathrm{Hence}$, radical addition would require in this case displacement of the solvent molecule. The relative acidity $\left(\mathrm{pK}_{\mathrm{a}}\right)$ of methanol in $\mathrm{C}_{6} \mathrm{D}_{6}$ and $\mathrm{CD}_{3} \mathrm{CN}$ does not appear to be known. Acid dissociation constants are available in polar solvents but cannot be easily assessed in non-polar ones such as benzene.

If RRT follows the OS-PCET pathway, the reaction should be facilitated in the solvent with higher dielectric constant (acetonitrile), because of the better stabilization of charged species (the transients $\left[\mathrm{Cu}^{\mathrm{II}} \mathrm{Br}\left(\mathrm{Me}_{6} \mathrm{TREN}\right)\right]^{+}$and $\mathrm{MeO}^{-}$would initially be produced, together with the product 
PMA-H, from neutral [Cu$\left.{ }^{\mathrm{I}} \mathrm{Br}\left(\mathrm{Me}_{6} \mathrm{TREN}\right)\right], \mathrm{PMA}^{\bullet}$ and $\left.\mathrm{MeOH}\right)$, hence the observed greater fraction of iBN in $\mathrm{C}_{6} \mathrm{D}_{6}$ seems to exclude this pathway. Finally, if an IS-PCET pathway is followed, the observed trends when changing solvent would be consistent with more favorable methanol coordination to $\left[\mathrm{Cu}^{\mathrm{I}} \mathrm{Br}\left(\mathrm{Me}_{6} \mathrm{TREN}\right)\right]$ in $\mathrm{C}_{6} \mathrm{D}_{6}$ than to $\left[\mathrm{Cu}^{\mathrm{I}}\left(\mathrm{Me}_{6} \mathrm{TREN}\right)\right]^{+}$in $\mathrm{CD}_{3} \mathrm{CN}$. In terms of the water/methanol comparison in $\mathrm{CD}_{3} \mathrm{CN}$, either a more favorable coordination of water than methanol to $\left[\mathrm{Cu}^{\mathrm{I}}\left(\mathrm{Me}_{6} \mathrm{TREN}\right)\right]^{+}$in $\mathrm{CD}_{3} \mathrm{CN}$ or a greater aptitude of the coordinated water to undergo the PCET process would explain the observed trend.

\section{(c) Decomposition in the presence of $\mathrm{Cu}^{\mathrm{I}}$ complexes with TPMA and BIPY}

Additional experiments, using copper complexes stabilized by the TPMA and BIPY ligands, were restricted to methanol as the source of hydrogen or deuterium. The results obtained in the presence of TPMA are collected in Table 3. The control experiments run in the absence of proton donor (entries 26 and 27) yielded again results identical to those in the absence of copper complex. The addition of increasing amount of $\mathrm{CH}_{3} \mathrm{OH}$ or $\mathrm{CD}_{3} \mathrm{OD}$ in $\mathrm{CD}_{3} \mathrm{CN}$ (entries 28-30 or 31-33, respectively) yields an increasing amount of iBN, with the biggest jump between 40 and 200 equivalents per AIBN. The same trend holds for the percent of $\mathrm{D}$ incorporation in the iBN product. The KIE induced a greater fraction of iBN with $\mathrm{CH}_{3} \mathrm{OH}$ relative to $\mathrm{CD}_{3} \mathrm{OD}$ ( $c f$. entries 30 and 33). Changing solvent from $\mathrm{CD}_{3} \mathrm{CN}$ to $\mathrm{C}_{6} \mathrm{D}_{6}$ shows the same trends as for the $\mathrm{Me}_{6}$ TREN system, with more iBN generated in the $\mathrm{C}_{6} \mathrm{D}_{6}$ solution relative to the $\mathrm{CD}_{3} \mathrm{CN}$ solution (e.g. $c f$. entries 34 and 30 , or 35 and 33$)$.

Table 3. Results of the thermal decomposition of AIBN in the presence of $\mathrm{Cu} / \mathrm{TPMA}$ systems. ${ }^{\mathrm{I}}$

\begin{tabular}{|l|l|l|l|l|l|}
\hline Entry & Solvent & $\mathrm{Cu}^{\mathrm{I}}$ complex & Additive/AIBN & iBN/dimer ${ }^{\mathrm{b}}$ & ${\text { \% } \mathrm{D} \text { in } \mathrm{iBN}^{\mathrm{c}}}$ \\
\hline 26 & $\mathrm{CD}_{3} \mathrm{CN}$ & {$\left[\mathrm{Cu}^{\mathrm{I}}(\mathrm{TPMA})\right]^{+} \mathrm{BF}_{4}^{-}$} & - & 0.09 & \\
\hline
\end{tabular}




\begin{tabular}{|l|l|l|l|l|l|}
\hline 27 & $\mathrm{C}_{6} \mathrm{D}_{6}$ & $\mathrm{CuBr} / \mathrm{TPMA}$ & - & 0.10 & \\
\hline 28 & $\mathrm{CD}_{3} \mathrm{CN}$ & {$[\mathrm{Cu}(\mathrm{TPMA})]^{+} \mathrm{BF}_{4}^{-}$} & $\mathrm{CH}_{3} \mathrm{OH}(2)$ & 0.10 & \\
\hline 29 & $\mathrm{CD}_{3} \mathrm{CN}$ & {$\left[\mathrm{Cu}^{\mathrm{I}}(\mathrm{TPMA})\right]^{+} \mathrm{BF}_{4}^{-}$} & $\mathrm{CH}_{3} \mathrm{OH}(40)$ & 0.14 & \\
\hline 30 & $\mathrm{CD}_{3} \mathrm{CN}$ & {$\left[\mathrm{Cu}^{\mathrm{I}}(\mathrm{TPMA})\right]^{+} \mathrm{BF}_{4}^{-}$} & $\mathrm{CH}_{3} \mathrm{OH}(200)$ & 3.6 & 1.3 \\
\hline 31 & $\mathrm{CD}_{3} \mathrm{CN}$ & {$\left[\mathrm{Cu}^{\mathrm{I}}(\mathrm{TPMA})\right]^{+} \mathrm{BF}_{4}^{-}$} & $\mathrm{CD}_{3} \mathrm{OD}(2)$ & 0.11 & 9.7 \\
\hline 32 & $\mathrm{CD}_{3} \mathrm{CN}$ & {$[\mathrm{Cu}(\mathrm{TPMA})]^{+} \mathrm{BF}_{4}^{-}$} & $\mathrm{CD}_{3} \mathrm{OD}(40)$ & 0.12 & 70.5 \\
\hline 33 & $\mathrm{CD}_{3} \mathrm{CN}$ & {$[\mathrm{Cu}(\mathrm{TPMA})]^{+} \mathrm{BF}_{4}^{-}$} & $\mathrm{CD}_{3} \mathrm{OD}(200)$ & 2.35 & \\
\hline 35 & $\mathrm{C}_{6} \mathrm{D}_{6}$ & $\mathrm{CuBr} / \mathrm{TPMA}$ & $\mathrm{CH}_{6} \mathrm{OH}(100)$ & 4.66 & 87.4 \\
\hline
\end{tabular}

${ }^{\mathrm{a}}$ Experiments in $\mathrm{CD}_{3} \mathrm{CN}:\left[\mathrm{Cu}^{\mathrm{I}}(\mathrm{MeCN})_{4}\right] \mathrm{BF}_{4} / \mathrm{TPMA} / \mathrm{AIBN}=1: 2: 0.5, \mathrm{~T}=80^{\circ} \mathrm{C}, 8 \mathrm{~h}$; experiments in $\mathrm{C}_{6} \mathrm{D}_{6}:[\mathrm{CuBr}] / \mathrm{Cu}^{0} / \mathrm{TPMA} / \mathrm{AIBN}=1: 4: 1.7: 1, \mathrm{~T}=75^{\circ} \mathrm{C}, 8 \mathrm{~h} .{ }^{\mathrm{b}}$ Ratio of the two $\mathrm{Me}_{2} \mathrm{C}$ resonances (see SI), hence equivalent to the moral ratio of AIBN leading to each product. ${ }^{c}$ Fraction of $\mathrm{Me}_{2} \mathrm{CD}(\mathrm{CN})$ in the iBN product, determined by ${ }^{1} \mathrm{H}$ NMR integration.

Table 4 reports all the results obtained using copper complexes in combination with the BIPY ligand. In this case, increasing the amount of methanol, whether regular or deuterated, whether in $\mathrm{CD}_{3} \mathrm{CN}$ or in $\mathrm{C}_{6} \mathrm{D}_{6}$, did not significantly alter the $\mathrm{iBN} /$ dimer ratio relative to the control experiments run in the absence of copper complex. On the other hand, there was a slight D incorporation when using $\mathrm{CD}_{3} \mathrm{OD}$. This $\mathrm{D}$ incorporation was much less significant in $\mathrm{CD}_{3} \mathrm{CN}$ than in $\mathrm{C}_{6} \mathrm{D}_{6}$.

Table 4. Results of the thermal decomposition of AIBN in the presence of $\mathrm{Cu} / \mathrm{BIPY}$ systems. ${ }^{\mathrm{a}}$

\begin{tabular}{|l|l|l|l|l|l|}
\hline Entry & Solvent & $\mathrm{Cu}^{\mathrm{I}}$ complex & Additive/AIBN & iBN/dimer ${ }^{\mathrm{b}}$ & \% D in iBN \\
\hline 36 & $\mathrm{CD}_{3} \mathrm{CN}$ & {$\left[\mathrm{Cu}^{\mathrm{I}}(\mathrm{BIPY})_{2}\right]^{+} \mathrm{BF}_{4}^{-}$} & - & 0.11 & \\
\hline 37 & $\mathrm{C}_{6} \mathrm{D}_{6}$ & $\mathrm{CuBr} / \mathrm{BIPY}$ & - & 0.07 & \\
\hline 38 & $\mathrm{CD}_{3} \mathrm{CN}$ & {$\left[\mathrm{Cu}^{\mathrm{I}}(\mathrm{BIPY})_{2}\right]^{+} \mathrm{BF}_{4}^{-}$} & $\mathrm{CH}_{3} \mathrm{OH}(2)$ & 0.10 & \\
\hline 39 & $\mathrm{CD}_{3} \mathrm{CN}$ & {$\left[\mathrm{Cu}^{\mathrm{I}}(\mathrm{BIPY})_{2}\right]^{+} \mathrm{BF}_{4}^{-}$} & $\mathrm{CH}_{3} \mathrm{OH}(40)$ & 0.08 & \\
\hline 40 & $\mathrm{CD}_{3} \mathrm{CN}$ & {$\left[\mathrm{Cu}^{\mathrm{I}}(\mathrm{BIPY})_{2}\right]^{+} \mathrm{BF}_{4}^{-}$} & $\mathrm{CH}_{3} \mathrm{OH}(200)$ & 0.11 & \\
\hline
\end{tabular}




\begin{tabular}{|l|l|l|l|l|l|}
\hline 41 & $\mathrm{CD}_{3} \mathrm{CN}$ & {$\left[\mathrm{Cu}^{\mathrm{I}}(\mathrm{BIPY})_{2}\right]^{+} \mathrm{BF}_{4}^{-}$} & $\mathrm{CD}_{3} \mathrm{OD}(2)$ & 0.11 & 2.4 \\
\hline 42 & $\mathrm{CD}_{3} \mathrm{CN}$ & {$\left[\mathrm{Cu}^{\mathrm{I}}(\mathrm{BIPY})_{2}\right]^{+} \mathrm{BF}_{4}^{-}$} & $\mathrm{CD}_{3} \mathrm{OD}(40)$ & 0.12 & 3.6 \\
\hline 43 & $\mathrm{CD}_{3} \mathrm{CN}$ & {$\left[\mathrm{Cu}^{\mathrm{I}}(\mathrm{BIPY})_{2}\right]^{+} \mathrm{BF}_{4}^{-}$} & $\mathrm{CD}_{3} \mathrm{OD}(200)$ & 0.15 & 4.2 \\
\hline 44 & $\mathrm{C}_{6} \mathrm{D}_{6}$ & $\mathrm{CuBr} / \mathrm{BIPY}$ & $\mathrm{CH}_{3} \mathrm{OH}(100)$ & 0.13 & \\
\hline 45 & $\mathrm{C}_{6} \mathrm{D}_{6}$ & $\mathrm{CuBr} / \mathrm{BIPY}$ & $\mathrm{CD}_{3} \mathrm{OD}(100)$ & 0.13 & 38.2 \\
\hline
\end{tabular}

${ }^{\mathrm{a}}$ Experiments in $\mathrm{CD}_{3} \mathrm{CN}$ : $\left[\mathrm{Cu}^{\mathrm{I}}(\mathrm{MeCN})_{4}\right] \mathrm{BF}_{4} / \mathrm{BIPY} / \mathrm{AIBN}=1: 4: 0.5, \mathrm{~T}=80^{\circ} \mathrm{C}, 8 \mathrm{~h}$; experiments in $\mathrm{C}_{6} \mathrm{D}_{6}:[\mathrm{CuBr}] / \mathrm{Cu}^{0} / \mathrm{BIPY} / \mathrm{AIBN}=1: 4: 3.4: 1, \mathrm{~T}=75^{\circ} \mathrm{C}, 8 \mathrm{~h} .{ }^{\mathrm{b}}$ Ratio of the two $\mathrm{Me}_{2} \mathrm{C}$ resonances (see SI), hence equivalent to the moral ratio of AIBN leading to each product. ${ }^{c}$ Fraction of $\mathrm{Me}_{2} \mathrm{CD}(\mathrm{CN})$ in the iBN product, determined by ${ }^{1} \mathrm{H}$ NMR integration.

\section{(d) Probing OS-PCET}

If RRT occurs via OS-PCET (Scheme 6), the copper(I) complex is oxidized to $\left[\mathrm{Cu}^{\mathrm{II}}(\mathrm{L})\right]^{2+}$ and the radical is reduced to anion, with concurrent or subsequent proton transfer from $\mathrm{ROH}(\mathrm{D})$. Either way, the aptitude to follow this decomposition pathway relative to RT (or CRT) should scale with the standard reduction potentials $\left(E^{\ominus}\right)$ of the copper complexes. The values of $E^{\ominus}$ for the $\left[\mathrm{Cu}^{\mathrm{II}}(\mathrm{L})\right]^{2+} /\left[\mathrm{Cu}^{\mathrm{I}}(\mathrm{L})\right]^{+}$redox couples with BIPY, TPMA, and $\mathrm{Me}_{6} \mathrm{TREN}$ are $0.18 \mathrm{~V}, 0.02 \mathrm{~V}$, and $-0.07 \mathrm{~V}$ vs SCE in acetonitrile. ${ }^{58}$ The iBN/dimer ratio, reflecting the aptitude to undergo RRT for the three complexes and 200 equiv of $\mathrm{CH}_{3} \mathrm{OH}$ or $\mathrm{CD}_{3} \mathrm{OD}$ in $\mathrm{CD}_{3} \mathrm{CN}$ is shown in Figure 1 . The value of $E^{\ominus}$ agrees with [Cu$\left.(\mathrm{BIPY})\right]^{+}$yielding the lowest degree of RRT, because it is the weakest reducing agent. However, the trend of reduction potentials for $\left[\mathrm{Cu}^{\mathrm{I}}(\mathrm{TPMA})\right]^{+}$and $\left[\mathrm{Cu}^{\mathrm{I}}\left(\mathrm{Me}_{6} \mathrm{TREN}\right)\right]^{+}$do not match the experimental degrees of RRT, which is greater for the weaker reducing agent $\left[\mathrm{Cu}^{\mathrm{I}}(\mathrm{TPMA})\right]^{+}$. Therefore, the electrochemical properties of the catalysts appear to rule out OS-PCET as the preferred mechanism for this decomposition pathway. Further evidence against the OS-PCET pathway is provided by the iBN/dimer ratio (hence the impact of RRT), which is greater in benzene than in $\mathrm{MeCN}$, whereas reactions involving the generation of charged species from neutral (or less charged) ones should be facilitated in solvents with a greater dielectric 
constant. Finally, a concerted OS-PCET process would be a termolecular reaction with an inherently low probability. ${ }^{59}$

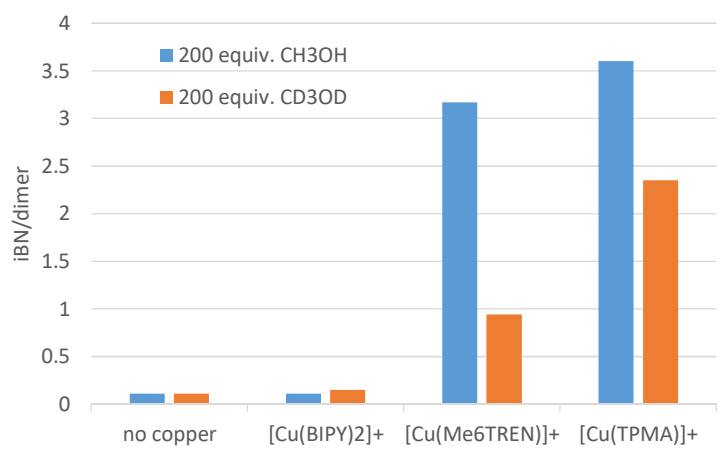

Figure 1. Observed isobutyronitrile(iBN)/tetramethylsuccinonitrile(dimer) ratio for the AIBN decomposition in the presence of 200 equivalents of $\mathrm{CH}_{3} \mathrm{OH}$ or $\mathrm{CD}_{3} \mathrm{OD}$ and the $[\mathrm{Cu}(\mathrm{L})]^{+}$ complexes $\left(\mathrm{L}=(\mathrm{BIPY})_{2}, \mathrm{Me}_{6} \mathrm{TREN}, \mathrm{TPMA}\right)$ in $\mathrm{CD}_{3} \mathrm{CN}$.

\section{(e) Investigation of water and methanol coordination to $[\mathrm{Cu}(\mathrm{L})]^{+}$}

The IS-PCET pathway requires coordination of the proton donor to the $\mathrm{Cu} / \mathrm{L}$ activator. Thus, the aptitude of the two proton donors $\left(\mathrm{H}_{2} \mathrm{O}\right.$ and $\mathrm{CH}_{3} \mathrm{OH}$ in $\mathrm{CD}_{3} \mathrm{CN}, \mathrm{CH}_{3} \mathrm{OH}$ in $\left.\mathrm{C}_{6} \mathrm{D}_{6}\right)$ to yield equilibrium amounts of $\mathrm{Cu}^{\mathrm{I}}$ adducts was investigated by ${ }^{1} \mathrm{H}$ NMR spectroscopy, using the $\mathrm{Me}_{6}$ TREN system. These investigations, however, could not give unambiguous evidence in favor of an interaction. The ${ }^{1} \mathrm{H}$ NMR spectra recorded for the $\left[\mathrm{Cu}^{\mathrm{I}}\left(\mathrm{Me}_{6} \mathrm{TREN}\right)\right]^{+} / \mathrm{H}_{2} \mathrm{O}$ experiment in $\mathrm{CD}_{3} \mathrm{CN}$ are shown in the SI, section S2. Before the addition of water, the spectrum shows the three expected signals of the $\mathrm{Me}_{6}$ TREN ligand in a 3:1:1 ratio, although broad, plus an additional small resonance at $2.23 \mathrm{ppm}$ probably due to the water impurity that was already present in the NMR solvent. The observation of broad ${ }^{1} \mathrm{H}$ NMR resonances is a common phenomenon for $\mathrm{Cu}^{\mathrm{I}}$ complexes, caused by the presence of paramagnetic $\mathrm{Cu}^{\mathrm{II}}$ impurities. These possibly originate from disproportionation of the in situ-generated $\left[\mathrm{Cu}^{\mathrm{I}}\left(\mathrm{Me}_{6} \mathrm{TREN}\right)\right]^{+}$. However, this equilibrium is not 
extensive in $\mathrm{MeCN}\left(K_{\text {disp }}=10^{-3}\right) \cdot{ }^{60}$ Addition of increasing amounts of $\mathrm{H}_{2} \mathrm{O}$ results in a continuous downfield shift of the $\mathrm{H}_{2} \mathrm{O}$ resonance while the $\mathrm{Me}_{6}$ TREN resonances further broaden. A rapid exchange between free and coordinated $\mathrm{H}_{2} \mathrm{O}$ that would only involve the diamagnetic $\mathrm{Cu}^{\mathrm{I}}$ complex would result instead in a signal sharpening and displacement toward the typical chemical shift value of free water in acetonitrile $(2.13 \mathrm{ppm}) .{ }^{61}$ Therefore, the observed behavior rather suggests a rapid exchange with a paramagnetic $\mathrm{Cu}^{\mathrm{II}}\left(\mathrm{H}_{2} \mathrm{O}\right)$ adduct, which would be generated in increasing proportions by addition of water, because the latter favors disproportionation of the $\left[\mathrm{Cu}^{\mathrm{I}}\left(\mathrm{Me}_{6} \mathrm{TREN}\right)\right]^{+}$complex. Similarly, electrochemical or spectrochemical titrations of $\mathrm{Cu}$ complexes in presence of various amounts of water did not provide conclusive evidence on water binding to $\mathrm{Cu}^{\mathrm{I}}$ (see SI, section S3). Is therefore impossible to obtain even qualitative evidence in favor of water binding to $\mathrm{Cu}^{\mathrm{I}}$ from this experiment.

The analogous addition of $\mathrm{CH}_{3} \mathrm{OH}$ to a $\left[\mathrm{Cu}^{\mathrm{I}}\left(\mathrm{Me}_{6} \mathrm{TREN}\right)\right]^{+}$solution in $\mathrm{CD}_{3} \mathrm{CN}$ provides analogous results, see SI, section S4. Notably, the $\mathrm{Me}_{6}$ TREN ligand resonances broaden upon addition of increasing methanol amounts. At the same time the $\mathrm{OH}$ resonance, while remaining relatively sharp, diverges toward lower-field position rather than converging toward the value of free $\mathrm{CH}_{3} \mathrm{OH}$ in $\mathrm{CD}_{3} \mathrm{CN}$. It is also notable that the coupling between the $\mathrm{CH}_{3}$ (doublet) and $\mathrm{OH}$ (quartet) protons for free $\mathrm{CH}_{3} \mathrm{OH}$, which is visible in the absence of the $\mathrm{Cu}$ complex (spectrum also shown in the SI), is washed out in the presence of the metal complex. The corresponding study of the addition of $\mathrm{CH}_{3} \mathrm{OH}$ to $\left[\mathrm{Cu}^{\mathrm{I}} \mathrm{Br}\left(\mathrm{Me}_{6} \mathrm{TREN}\right)\right]$ in $\mathrm{C}_{6} \mathrm{D}_{6}$ exhibits again the same behavior. In this case, the methanol $\mathrm{OH}$ resonance is not clearly visible in the absence of copper, in agreement with the literature, ${ }^{61}$ but becomes observable as a weak and broad resonance in the presence of the copper complex, once again broadening and shifting downfield as the methanol amount is increased (SI, section S5). 


\section{(f) DFT calculations}

Since no experimental methods are available to assess the ability of the various copper systems to bind proton donor molecules on one side and the cyanoisopropyl radical on the other, we turned to computational studies. These were restricted to the cationic $\left[\mathrm{Cu}^{\mathrm{I}}(\mathrm{L})_{\mathrm{n}}\right]^{+}$complexes in acetonitrile solution and their interaction with water and with the cyanoisopropyl radical. However, since the complexes are likely to be solvated in acetonitrile, the 5 -coordinate $\left[\mathrm{Cu}^{\mathrm{I}}(\mathrm{L})_{\mathrm{n}}\left(\mathrm{CH}_{3} \mathrm{CN}\right)\right]^{+}$system was also considered. The calculations were carried out using a DFT approach (see Computational Details), using the full molecular systems with dispersion and solvation corrections in acetonitrile. The calculated values are reported as Gibbs free energies at $298.15 \mathrm{~K}$ in the condensed phase $1 \mathrm{M}$ standard state. On the basis of our previous work, we believe that the chosen functional/basis set combination give relatively accurate energy estimates, ${ }^{20}$ but we do not put a large amount of faith on the quantitative results. However, we believe that the calculated trends should accurately reproduce the experimental reality. The interaction energies are shown in Table 5 and selected optimized structural parameters are reported in Table 6, while views and Cartesian coordinates of all optimized geometries are reported in the SI (section S5).

Table 5. DFT-estimated Gibbs' free energies $\left(\Delta G_{298.15, \mathrm{MeCN}, 1 \mathrm{M}}\right.$ in $\left.\mathrm{kcal} / \mathrm{mol}\right)$ for the formation of $\left[\mathrm{Cu}^{\mathrm{I}}(\mathrm{L})_{\mathrm{n}}\left(\mathrm{CH}_{3} \mathrm{CN}\right)\right]^{+},\left[\mathrm{Cu}^{\mathrm{I}}(\mathrm{L})_{\mathrm{n}}\left(\mathrm{H}_{2} \mathrm{O}\right)\right]^{+}$, and $\left[\mathrm{Cu}^{\mathrm{II}}\left\{\mathrm{CMe}_{2}(\mathrm{CN})\right\}(\mathrm{L})_{\mathrm{n}}\right]^{+}$from $\left[\mathrm{Cu}^{\mathrm{I}}(\mathrm{L})_{\mathrm{n}}\right]^{+}$plus $\mathrm{CH}_{3} \mathrm{CN}$, $\mathrm{H}_{2} \mathrm{O}$ or $\mathrm{Me}_{2} \mathrm{C}^{\bullet}(\mathrm{CN})$, respectively $\left(\mathrm{L}=\mathrm{Me}_{6}\right.$ TREN and TPMA, $\left.\mathrm{n}=1 ; \mathrm{L}=\mathrm{BIPY}, \mathrm{n}=2\right)$.

\begin{tabular}{|l|c|c|c|c|}
\hline $\mathrm{L}$ & {$\left[(\mathrm{L})_{n} \mathrm{Cu}^{\mathrm{I}}-\mathrm{NCCH}_{3}\right]^{+}$} & {$\left[(\mathrm{L})_{\mathrm{n}} \mathrm{Cu}^{\mathrm{I}}-\mathrm{OH}_{2}\right]^{+}$} & {$\left[\left(\mathrm{L}_{\mathrm{n}} \mathrm{Cu}^{\mathrm{II}}-\mathrm{CMe}_{2}(\mathrm{CN})\right]^{+}\right.$} & {$\left[(\mathrm{L})_{\mathrm{n}} \mathrm{Cu}^{\mathrm{II}}-\mathrm{N}=\mathrm{C}=\mathrm{CMe}_{2}\right]^{+}$} \\
\hline $\mathrm{Me}_{6}$ TREN, $\mathrm{n}=1$ & -2.6 & -1.1 & -6.6 & -12.9 \\
\hline TPMA, $\mathrm{n}=1$ & -0.5 & -5.9 & -11.9 & -12.6 \\
\hline
\end{tabular}




\begin{tabular}{|l|l|l|l|c|}
\hline BIPY, $\mathrm{n}=2$ & +5.8 & ${ }^{a}$ & ${ }^{a}$ & +2.9 \\
\hline
\end{tabular}

${ }^{\text {a }}$ A stable adduct could not be obtimized (see text).

Table 6. Selected structural parameters (distances in $\AA$, angles in degrees) for the optimized $\left[\mathrm{Cu}^{\mathrm{II}}(\mathrm{L})_{\mathrm{n}}\left(\mathrm{CMe}_{2} \mathrm{CN}\right)\right]^{+}, \quad\left[\mathrm{Cu}^{\mathrm{II}}(\mathrm{L})_{\mathrm{n}}\left(\mathrm{N}=\mathrm{C}=\mathrm{CMe}_{2}\right)\right]^{+}, \quad\left[\mathrm{Cu}^{\mathrm{I}}(\mathrm{L})_{\mathrm{n}}\left(\mathrm{CH}_{3} \mathrm{CN}\right)\right]^{+} \quad$ and $\quad\left[\mathrm{Cu}^{\mathrm{I}}(\mathrm{L})_{\mathrm{n}}\left(\mathrm{H}_{2} \mathrm{O}\right)\right]^{+}$ structures.

\begin{tabular}{|c|c|c|c|}
\hline Parameter & MesTREN & TPMA & $(\text { BIPY })_{2}$ \\
\hline \multicolumn{4}{|c|}{$\left[\mathrm{Cu}^{\mathrm{II}}(\mathrm{L})_{\mathrm{n}}\left(\mathrm{CMe}_{2} \mathrm{CN}\right)\right]^{+}$systems } \\
\hline $\mathrm{Cu}-\mathrm{C}$ & 2.160 & 2.134 & \\
\hline $\mathrm{Cu}-\mathrm{N}_{\mathrm{ax}}$ & 2.260 & 2.223 & \\
\hline $\mathrm{Cu}-\mathrm{N}_{\mathrm{eq}}$ & $2.384,2.409,2.363$ & $2.210,2.211,2.207$ & \\
\hline Average $\mathrm{Cu}-\mathrm{N}_{\mathrm{eq}}$ & 2.385 & 2.209 & \\
\hline $\mathrm{C}-\mathrm{Cu}-\mathrm{N}_{\mathrm{ax}}$ & 171.46 & 174.69 & \\
\hline $\mathrm{C}-\mathrm{Cu}-\mathrm{N}_{\mathrm{eq}}$ & $99.26,101.40,100.96$ & $102.36,104.82,102.78$ & \\
\hline \multicolumn{4}{|c|}{$\left[\mathrm{Cu}^{\mathrm{II}}(\mathrm{L})_{\mathrm{n}}\left(\mathrm{N}=\mathrm{C}=\mathrm{CMe}_{2}\right)\right]^{+}$systems } \\
\hline $\mathrm{Cu}-\mathrm{N}$ & 1.983 & 2.008 & 2.040 \\
\hline $\mathrm{Cu}-\mathrm{N}_{\mathrm{ax}}$ & 2.227 & 2.307 & $2.168,2.220(\mathrm{eq})$ \\
\hline $\mathrm{Cu}-\mathrm{N}_{\mathrm{eq}}$ & $2.315,2.321,2.214$ & $2.094,2.150,2.166$ & $2.125,2.164(\mathrm{ax})$ \\
\hline Average $\mathrm{Cu}-\mathrm{N}_{\mathrm{eq}}$ & 2.283 & 2.137 & \\
\hline $\mathrm{N}-\mathrm{Cu}-\mathrm{N}_{\mathrm{ax}}$ & & & $120.67,137.39(\mathrm{eq})$ \\
\hline $\mathrm{N}-\mathrm{Cu}-\mathrm{N}_{\mathrm{eq}}$ & $93.72,96,21,105.17$ & $106.98,100.83,100.20$ & $95.04,89.44(\mathrm{ax})$ \\
\hline \multicolumn{4}{|c|}{$\left[\mathrm{Cu}^{\mathrm{I}}(\mathrm{L})_{\mathrm{n}}\left(\mathrm{CH}_{3} \mathrm{CN}\right)\right]^{+}$systems } \\
\hline $\mathrm{Cu}-\mathrm{N}(\mathrm{MeCN})$ & 1.976 & 2.038 & 1.984 \\
\hline $\mathrm{Cu}-\mathrm{N}_{\mathrm{ax}}$ & 2.332 & 2.438 & $2.108,2.108(\mathrm{eq})$ \\
\hline $\mathrm{Cu}-\mathrm{N}_{\mathrm{eq}}$ & $2.336,2.321,2.342$ & $2.142,2.141,2.143$ & $2.325,2.323(\mathrm{ax})$ \\
\hline $\mathrm{N}-\mathrm{Cu}-\mathrm{N}_{\mathrm{ex}}$ & 179.29 & 179.93 & $125.25,125.41(\mathrm{eq})$ \\
\hline $\mathrm{N}-\mathrm{Cu}-\mathrm{N}_{\mathrm{eq}}$ & $100.79,101.39,100.53$ & $105.08,105.12,105.04$ & $93.75,93.76(\mathrm{ax})$ \\
\hline \multicolumn{4}{|c|}{$\left[\mathrm{Cu}^{\mathrm{I}}(\mathrm{L})_{\mathrm{n}}\left(\mathrm{CH}_{3} \mathrm{CN}\right)\right]^{+}$systems } \\
\hline $\mathrm{Cu}-\mathrm{O}$ & 2.435 & 2.458 & \\
\hline $\mathrm{Cu}-\mathrm{N}_{\mathrm{ax}}$ & 2.280 & 2.315 & \\
\hline $\mathrm{Cu}-\mathrm{N}_{\mathrm{eq}}$ & $2.225,2.224,2.233$ & $2.071,2.078,2.065$ & \\
\hline $\mathrm{O}-\mathrm{Cu}-\mathrm{N}_{\mathrm{ax}}$ & 179.69 & 164.97 & \\
\hline $\mathrm{O}-\mathrm{Cu}-\mathrm{N}_{\mathrm{eq}}$ & $96.64,97.16,97.09$ & $93.94,92.30,114.76$ & \\
\hline
\end{tabular}

The binding energies for $\mathrm{CH}_{3} \mathrm{CN}$ are very small and negative (i.e. the interaction is favorable) only for the Me $\mathrm{e}_{6} \mathrm{TREN}$ and TPMA systems. The $\mathrm{CH}_{3} \mathrm{CN}$ adduct for the BIPY system, although giving an optimized local energy minimum, is endoergic relative to the sum of the separate 
$\left[\mathrm{Cu}^{\mathrm{I}}(\mathrm{BIPY})_{2}\right]^{+}$and $\mathrm{MeCN}$. The lower binding aptitude of the BIPY system may be associated to the greater stability of the $\left[\mathrm{Cu}^{\mathrm{I}}(\mathrm{BIPY})_{2}\right]^{+}$tetrahedral geometry, whereas the geometry of the complexes with tripodal ligands, $\left[\mathrm{Cu}^{\mathrm{I}}\left(\mathrm{Me}_{6} \mathrm{TREN}\right)\right]^{+}$and $\left[\mathrm{Cu}^{\mathrm{I}}(\mathrm{TPMA})\right]^{+}$, is strained. The trigonal bipyramidal structure of the $\left[\mathrm{Cu}^{\mathrm{I}}(\mathrm{L})_{\mathrm{n}}\left(\mathrm{CH}_{3} \mathrm{CN}\right)\right]^{+}$product, on the other hand, can better adjust all ligands.

Water binding also appears weak according to the calculations. For the $\mathrm{Me}_{6} \mathrm{TREN}$ system, binding water is less favorable than acetonitrile, though still slightly exoergic relative to the 4coordinated unsaturated complex. For the TPMA system, on the other hand, the calculations indicate that water binds better than acetonitrile. For the BIPY system, a local minimum for a $\mathrm{Cu}^{\mathrm{I}}-$ bound water adduct could not even be located, yielding instead a van der Waals $\left[\mathrm{Cu}^{\mathrm{I}}(\mathrm{BIPY})_{2} \cdots \mathrm{OH}_{2}\right]^{+}$adduct that features a loose interaction between the $\mathrm{O}$ atom and a $\mathrm{CH}$ group of one of the BIPY aromatic rings.

The interaction with the cyanoisopropyl radical was found possible in two different ways, leading to C-bonded and $\mathrm{N}$-bonded isomers. In the free radical, the spin density resides mostly on the tertiary $\mathrm{C}$ atom (0.731), but a significant amount (0.342) is also located on the cyano $\mathrm{N}$ atom. The most relevant spin density values for all paramagnetic systems are shown in Figure 2. Metal binding through the $\mathrm{C}$ atom, even though the radical is stabilized and tertiary, is energetically favored for the most reactive $\mathrm{Me}_{6}$ TREN and TPMA systems. On the other hand, no stable energy minimum could be located for the less reactive BIPY system. Rather, the geometry optimization for this system converged to a van der Waals $\left[\mathrm{Cu}^{\mathrm{I}}(\mathrm{BIPY})_{2} \cdots \mathrm{NC}\left(\mathrm{CMe}_{2}\right)\right]^{+}$adduct, similar to that already described with water (loose interaction between the $\mathrm{N}$ atom and a $\mathrm{CH}$ group of a BIPY aromatic rings). In this adduct, which is located at $+3.7 \mathrm{kcal} / \mathrm{mol}$ relative from the two separate reagents, the spin density is entirely located on the cyanoisopropyl group, with values on the $\mathrm{C}$ 
and $\mathrm{N}$ atoms very close to those of the free radical, while the $\mathrm{Cu}$ atom has no spin density. On the other hand, the organocopper(II) products with the two tripodal ligands show an approximately equal share of the spin density between the $\mathrm{Cu}$ atom and the $\mathrm{Cu}$-bonded $\mathrm{C}$ atom, in agreement with the weak bonding interaction, plus a comparatively reduced but non-zero spin density on the cyanoisopropyl $\mathrm{N}$ atom, see Figure 2.

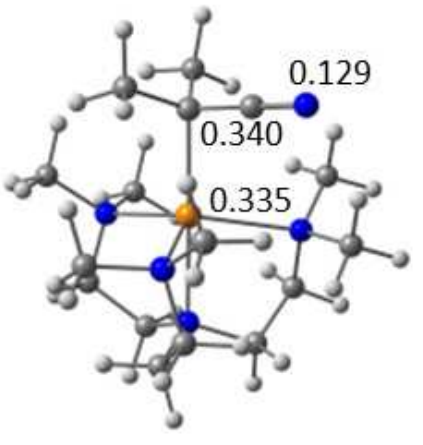

$\left[\mathrm{Cu}\left(\mathrm{CMe}_{2} \mathrm{CN}\right)\left(\mathrm{Me}_{6} \mathrm{TREN}\right]^{+}\right.$

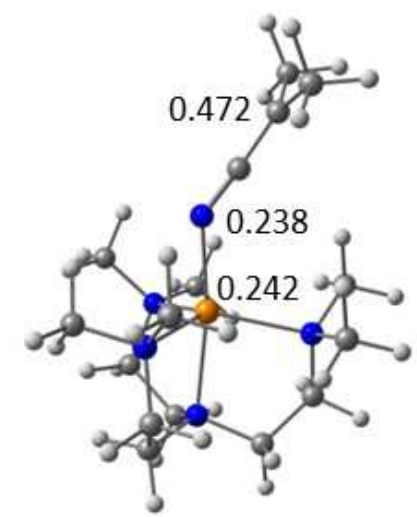

$\left[\mathrm{Cu}\left(\mathrm{N}=\mathrm{C}=\mathrm{CMe}_{2}\right)\left(\mathrm{Me}_{6} \mathrm{TREN}\right)\right]^{+}$
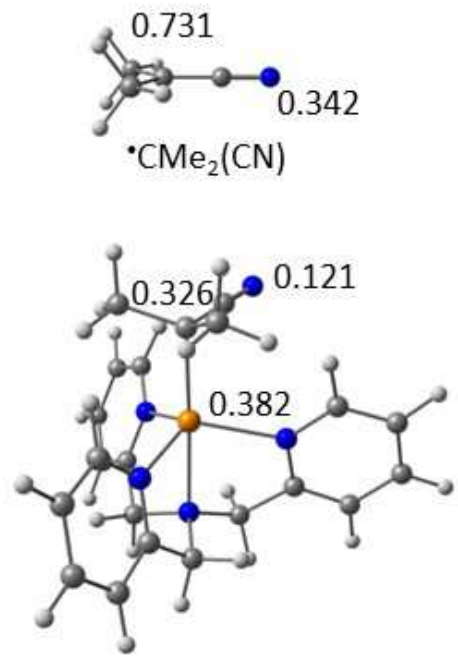

$\left[\mathrm{Cu}\left(\mathrm{CMe}_{2} \mathrm{CN}\right)(\mathrm{TPMA})\right]^{+}$

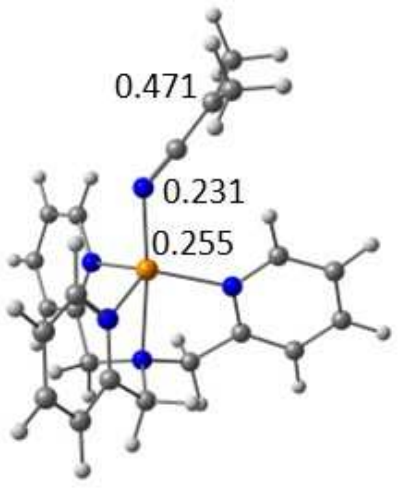

$\left[\mathrm{Cu}\left(\mathrm{N}=\mathrm{C}=\mathrm{CMe}_{2}\right)(\mathrm{TPMA})\right]^{+}$

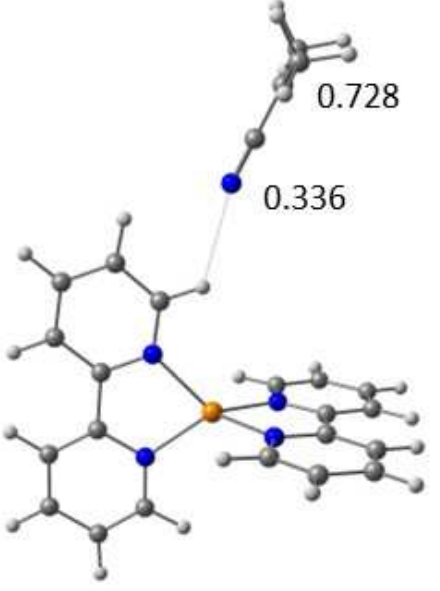

$\left[\mathrm{Cu}\left(\mathrm{CMe}_{2} \mathrm{CN}\right)(\mathrm{BIPY})\right]^{+}$

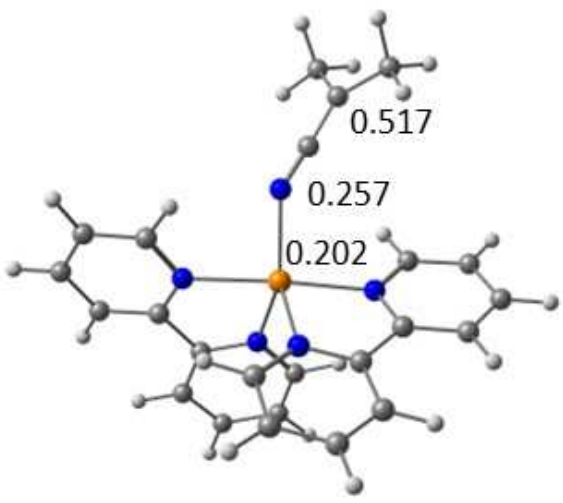

$\left[\mathrm{Cu}\left(\mathrm{N}=\mathrm{C}=\mathrm{CMe}_{2}\right)(\mathrm{BIPY})\right]^{+}$

Figure 2. Views of all optimized paramagnetic structures with the main Mulliken spin densities. 
Strikingly, the alternative binding of the cyanopropyl radical through the $\mathrm{N}$ atom, leading to the keteniminato $\left[(\mathrm{L})_{\mathrm{n}} \mathrm{Cu}^{\mathrm{II}}-\mathrm{N}=\mathrm{C}=\mathrm{CMe}_{2}\right]^{+}$isomer, is even more favorable. It is worth noting that metal binding of a cyano-stabilized radical via the $\mathrm{N}$ atom has been previously proposed for the addition of the ${ }^{\circ} \mathrm{C}(\mathrm{CN})(\mathrm{Me}) \mathrm{CH}_{2} \mathrm{C}(\mathrm{OMe}) \mathrm{Me}_{2}$ radical generated from 2,2'-azobis(4-methoxy-2,4dimethylvaleronitrile $)(\mathrm{V}-70)$ to $\mathrm{Co}(\mathrm{acac})_{2}$ (acac $=$ acetylacetonate $)$, on the basis of both experimental and computational evidence. ${ }^{62}$ Other keteniminato complexes of transition metals are also known, such as $\left[\mathrm{IrCp} *\left(\mathrm{~N}=\mathrm{C}=\mathrm{CPh}_{2}\right)(\mathrm{Ph})\left(\mathrm{PMe}_{3}\right)\right]\left(\mathrm{Cp}^{*}=\text { petalmethylcyclopentadienyl }\right)^{63}$ and $\left[\mathrm{Ru}(\mathrm{dmpe})_{2}(\mathrm{H})(\mathrm{N}=\mathrm{C}=\mathrm{CHAr})\right]\left(\mathrm{Ar}=\mathrm{Ph}, p-\mathrm{C}_{6} \mathrm{H}_{4} \mathrm{CF}_{3} ;\right.$ dmpe $=$ 1,2-bis(dimethylphosphino)ethane), ${ }^{64,65}$ although they were not obtained by radical routes.

The energetic advantage for $\mathrm{N}$-binding is greater for the $\mathrm{Me}_{6} \mathrm{TREN}$ system $(6.3 \mathrm{kcal} / \mathrm{mol})$ than for the TPMA system, for which the N-bonded complex is more stable than the C-bonded isomer by only $0.7 \mathrm{kcal} / \mathrm{mol}$. The reason for this difference in relative stabilization can be appreciated from the structural parameters in Table 6 . The $\mathrm{NMe}_{2}$ groups of $\mathrm{Me}_{6} \mathrm{TREN}$ generate a significantly greater steric repulsion than the TPMA pyridine rings on the C-bonded tertiary radical, which is greater than the steric repulsion exerted on the isomeric N-bonded fragment. This can be judged by the greater increase of the $\mathrm{Cu}-\mathrm{N}_{\mathrm{eq}}$ distances from the $\mathrm{N}$-bound to the $\mathrm{C}$-bound isomer (the average $\mathrm{Cu}^{\mathrm{II}}-\mathrm{N}_{\text {eq }}$ distance increases from 2.227 to $2.385 \AA$, a $0.158 \AA$ increase, for the $\mathrm{Me}_{6}$ TREN system, vs. an increase from 2.137 to $2.209 \AA$, only a $0.072 \AA$ increase, for the TPMA system). The N-bound isomer yields a stable minimum also for the less reactive BIPY system, but this is endoergic relative to the separate reagents. In these three keteniminato $\mathrm{Cu}^{\mathrm{II}}$ derivatives, the spin density is predominantly located on the isopropyl $\mathrm{C}$ atom $\left(0.472,0.471\right.$ and 0.517 for $\mathrm{Me}_{2} \mathrm{TREN}$, TPMA and BIPY systems, respectively) with the rest equally shared by the directly bonded $\mathrm{Cu}$ and $\mathrm{N}$ atoms. In this respect, the assignment of the oxidation state II to the copper atom in these 
radical adducts is just a formality, because the majority of the spin density, particularly for the $\mathrm{N}$ bound keteniminato isomer, still resides on the cyanoisopropyl group. It is of interest to note that the related cyanomethyl group $\left(\mathrm{CH}_{2} \mathrm{CN}\right)$ was found bonded in a $\mathrm{Cu}^{\mathrm{II}}$ complex as a cyanosubstituted alkyl ligand via the $\mathrm{C}$ atom, rather than as a keteniminato ligand via the $\mathrm{N}$ atom. ${ }^{66}$

In conclusion, the DFT calculations indicate that there is substantial difference between the two tripodal ligands $\mathrm{Me}_{6}$ TREN and TPMA on one side and the bidentate BIPY system on the other one. The two systems with the tripodal ligands have greater aptitude than that with BIPY to bind both water and the cyanoisopropyl radical. While $\left[\mathrm{Cu}^{\mathrm{I}}(\mathrm{BIPY})_{2}\right]^{+}$shows no thermodynamic gain for binding either a neutral molecule or the organic radical, the Me6TREN and TPMA systems can be stabilized by addition of both a neutral donor molecule (acetonitrile, water) and the cyanoisopropyl radical. The stabilization provided by the radical is much greater and appears more favorable when binding occurs via the $\mathrm{N}$ atom to yield a less bulky $\mathrm{Cu}^{\mathrm{II}}-\mathrm{N}=\mathrm{C}=\mathrm{CMe}_{2}$ moiety than via the $\mathrm{C}$ atom to yield an organometallic derivative. The experimental observation of a much greater impact of $\left[\mathrm{H}_{2} \mathrm{O}\right]$ and $\left[\mathrm{CH}_{3} \mathrm{OH}\right]$ on the product distribution for the $\mathrm{Me}_{6}$ TREN and TPMA system than for the BIPY system is thus consistent with both the OMRP and the IS-PCET pathways in RRT (Scheme 6).

\section{(g) Protonolysis with triethylammonium salts}

In order to gain additional information on the RRT mechanism, we have finally opted for the use of a proton donor that is devoid of coordinating properties, namely a triethylammonium salt. This proton donor cannot operate via the IS-PCET pathway, whereas its greater acidity relative to water and methanol should enhance the OMRP pathway. Two different $\left[\mathrm{Et}_{3} \mathrm{NH}\right]^{+}$salts, bromide and tetrafluoroborate, were used for the AIBN decomposition experiments, which were conducted 
only in $\mathrm{CD}_{3} \mathrm{CN}$ for solubility reasons. The results are collected in Table 7. The blank experiment run in the absence of copper complex (entry 46) yields a very close iBN/dimer ratio to that of the decomposition without proton donor (Table 1, entry 1).

Table 7. Results of the thermal decomposition of AIBN in the presence of $\left[\mathrm{Et}_{3} \mathrm{NH}\right]^{+}$salts as proton donors and different $\mathrm{Cu} / \mathrm{L}$ systems. ${ }^{\mathrm{a}}$

\begin{tabular}{|l|l|l|l|l|}
\hline Entry & Anion & $\mathrm{Cu}^{\mathrm{I}}$ complex & {$\left[\mathrm{Et}_{3} \mathrm{NH}\right]^{+} / \mathrm{AIBN}$} & iBN/dimer ${ }^{\mathrm{b}}$ \\
\hline 46 & $\mathrm{BF}_{4}^{-}$ & - & $\mathrm{c}$ & 0.05 \\
\hline 47 & $\mathrm{BF}_{4}^{-}$ & {$\left[\mathrm{Cu}^{\mathrm{I}}\left(\mathrm{Me}_{6} \mathrm{TREN}^{-}\right]^{+} \mathrm{BF}_{4}^{-}\right.$} & 2 & 5.11 \\
\hline 48 & $\mathrm{BF}_{4}^{-}$ & {$\left[\mathrm{Cu}^{\mathrm{I}}\left(\mathrm{Me}_{6} \mathrm{TREN}^{-}\right]^{+} \mathrm{BF}_{4}^{-}\right.$} & 40 & 7.68 \\
\hline 49 & $\mathrm{Br}^{-}$ & {$\left[\mathrm{Cu}^{\mathrm{I}}\left(\mathrm{Me}_{6} \mathrm{TREN}^{-}\right]^{+} \mathrm{BF}_{4}^{-}\right.$} & 2 & 5.56 \\
\hline 50 & $\mathrm{BF}_{4}^{-}$ & {$\left[\mathrm{Cu}^{\mathrm{I}}(\mathrm{TPMA})\right]^{+} \mathrm{BF}_{4}^{-}$} & 2 & 2.58 \\
\hline 51 & $\mathrm{BF}_{4}^{-}$ & {$\left[\mathrm{Cu}^{\mathrm{I}}(\mathrm{TPMA})\right]^{+} \mathrm{BF}_{4}^{-}$} & 40 & 9.81 \\
\hline 52 & $\mathrm{BF}_{4}^{-}$ & {$\left[\mathrm{Cu}^{\mathrm{I}}(\mathrm{BIPY})_{2}\right]^{+} \mathrm{BF}_{4}^{-}$} & 2 & 0.15 \\
\hline 53 & $\mathrm{BF}_{4}^{-}$ & {$\left[\mathrm{Cu}^{\mathrm{I}}(\mathrm{BIPY})_{2}\right]^{+} \mathrm{BF}_{4}^{-}$} & 40 & 1.18 \\
\hline
\end{tabular}

${ }^{\mathrm{a}}\left[\mathrm{Cu}^{\mathrm{I}}(\mathrm{MeCN})_{4}\right] \mathrm{BF}_{4} / \mathrm{L} / \mathrm{AIBN}=1:\left(2\right.$ for $\mathrm{L}=\mathrm{Me}_{6} \mathrm{TREN}$ and TPMA; 1 for $\left.\mathrm{L}=\mathrm{BIPY}\right): 0.5, \mathrm{~T}=$ $80^{\circ} \mathrm{C}, 8 \mathrm{~h}^{\mathrm{b}}{ }^{\mathrm{b}}$ Ratio of the two $\mathrm{Me}_{2} \mathrm{C}$ resonances (see $\mathrm{SI}$ ), hence equivalent to the moral ratio of AIBN leading to each product. ${ }^{c}\left[\mathrm{Et}_{3} \mathrm{NH}\right]^{+} / \mathrm{AIBN}=2$.

The results clearly show that the $\mathrm{Et}_{3} \mathrm{NH}^{+}$salts enhance $\mathrm{RRT}$ relative to water and methanol. With $\mathrm{Me}_{6} \mathrm{TREN}$, an RRT/dimerization ratio of 5.11 was obtained when using only two equivalents of $\mathrm{Et}_{3} \mathrm{NH}^{+} \mathrm{BF}_{4}^{-}$per $\mathrm{AIBN}$ (entry 47), whereas the equivalent amount of $\mathrm{CH}_{3} \mathrm{OH}$ gives a ratio of 0.20 (Table 2, entry 16). This ratio further increased to 7.68 with 40 equivalents (entry 48), vs. 1.65 with the same amount of $\mathrm{CH}_{3} \mathrm{OH}$ (Table 2, entry 15). These ratios are even greater than that obtained with 200 equiv. of $\mathrm{H}_{2} \mathrm{O}$ (4.28, Table 2, entry 12). Using $\mathrm{Et}_{3} \mathrm{NH}^{+} \mathrm{Br}^{-}$gave an essentially identical result (entry 49) to that of the $\mathrm{BF}_{4}^{-}$salt, in agreement with the weak association of $\mathrm{Br}^{-}$to 
$\left[\mathrm{Cu}^{\mathrm{I}}\left(\mathrm{Me}_{6} \mathrm{TREN}\right)\right]^{+}$in acetonitrile ${ }^{67}$ For the TPMA complex, the RRT is equally enhanced (entries 50-51, $c f$. with the equivalent amounts of $\mathrm{CH}_{3} \mathrm{OH}$ in Table 3, entries 28 and 29). Finally, even the BIPY system, for which a low impact of RRT was shown even in the presence of 200 equivalents of $\mathrm{CH}_{3} \mathrm{OH}$ (iBN/dimer $=0.11$, Table 4, entry 40), exhibits an enhancement of RRT when using the $\mathrm{Et}_{3} \mathrm{NH}^{+}$salt (entries 52 and 53), even though the impact of RRT remains largely inferior with respect to the use of the more reducing complexes with Me 6 TREN and TPMA.

Thus, it clearly appears that RRT occurs primarily by what has been defined as the "OMRP route" in Scheme 6, although the DFT result rather support the formation of an $\mathrm{N}$-bound $\mathrm{Cu}^{\mathrm{II}}$ intermediate, rather than an organometallic complex. The acidic additive (water, methanol, or $\mathrm{Et}_{3} \mathrm{NH}^{+}$) can then provide a proton to cleave the $\mathrm{Cu}-\mathrm{N}$ bond heterolytically and the extent of this process is highly dependent on the proton donor acidity. The observed isobutyronitrile product can result from either direct protonation of the conjugated $\mathrm{C}$ atom, or cleavage of the $\mathrm{Cu}^{\mathrm{II}}-\mathrm{N}$ bond with release of the ketenimine $\mathrm{Me}_{2} \mathrm{C}=\mathrm{C}=\mathrm{NH}$, which subsequently tautomerizes. ${ }^{68}$

The experimental results are actually rather consistent with the DFT predictions, because formation of the $\left[\mathrm{Cu}^{\mathrm{I}}(\mathrm{L})_{\mathrm{n}}\right]^{+}$adduct with $\mathrm{Me}_{2} \mathrm{C}^{\bullet}(\mathrm{CN})$ provides greater stability than coordination of water or acetonitrile. The stronger stabilization predicted for the Me ${ }_{6}$ TREN and TPMA system is in line with the greater fraction of RRT product obtained for those systems. Concerning the BIPY system, the DFT calculations show a slightly endoergic adduct formation with the radical via the $\mathrm{N}$ atom (e.g. the keteniminato form). However, the relative energy of this derivative makes it a thermally accessible intermediate for the RRT process. Therefore, it seems that the agreement between the calculations and the experimental result (for the RRT in the presence of $\mathrm{Et}_{3} \mathrm{NH}^{+}$) is good even at the semi-quantitative level. As a final note, we can conclude that while the experiments run with $\mathrm{Et}_{3} \mathrm{NH}^{+}$definitely prove the intervention of a pathway involving an adduct 
between the radical and the $\mathrm{Cu} / \mathrm{L}$ complex, this does not exclude the contribution (or even the exclusive action) of an IS-PCET pathway in the presence of water or methanol.

\section{Conclusion}

We have analyzed the distribution of the cyanoisopropyl radical termination products in the presence of proton donors (water, methanol triethylammonium salts) and copper(I) complexes stabilized by three different ligand systems (Me $6{ }_{6}$ TREN, TPMA and BIPY) in two different solvents $\left(\mathrm{CD}_{3} \mathrm{CN}, \mathrm{C}_{6} \mathrm{D}_{6}\right)$. The simultaneous presence of copper and proton donor provides access to a reductive radical termination (RRT) with formation of isobutyronitrile by stoichiometric transfer of an electron from the copper complex and by a proton from the acidic additive. The extent of RRT is affected by the nature of the $\mathrm{Cu}$ complex, of the proton donor and of the solvent in the orders BIPY $<<\mathrm{Me}_{6}$ TREN $\sim$ TPMA, $\mathrm{CD}_{3} \mathrm{OD}<\mathrm{CH}_{3} \mathrm{OH}, \mathrm{D}_{2} \mathrm{O}<\mathrm{H}_{2} \mathrm{O}, \mathrm{CH}_{3} \mathrm{OH}(\mathrm{D})<\mathrm{H}(\mathrm{D})_{2} \mathrm{O}$ $<\mathrm{Et}_{3} \mathrm{NH}^{+}$, and $\mathrm{CD}_{3} \mathrm{CN}<\mathrm{C}_{6} \mathrm{D}_{6}$.

The most surprising and unexpected result of this study, as suggested by the DFT calculations, is the tendency of the most reactive $\left[\mathrm{Cu}(\mathrm{L})_{\mathrm{n}}\right]^{+}$complexes (i.e. those stabilized by the $\mathrm{Me}_{6} \mathrm{TREN}$ and TPMA ligands, $n=1$ ) to trap the cyanoisopropyl radical, a stabilized radical for which we considered trapping by a transition metal to be unlikely, and yield stabilized adducts that may be formally described as copper(II) complexes, though the spin density transfer from the organic radical to the metal is quite partial. No evidence for such an interaction was found for the less reactive system $(\mathrm{L}=$ BIPY, $\mathrm{n}=2)$. It is also relevant to note that $\mathrm{Cu}^{\mathrm{I}}$ is not known for forming stable organocopper(II) derivatives, even with strong radicals. ${ }^{45}$ Even more surprising and unexpected is the indication by the DFT calculations that the N-bound keteniminato isomer is more stable than the C-bound cyanoisopropyl organometallic derivative, particularly for the more sterically demanding $\mathrm{Me}_{6} \mathrm{TREN}$ system. 
Coordination of donor molecules (acetonitrile, water) to the $\left[\mathrm{Cu}(\mathrm{L})_{\mathrm{n}}\right]^{+}$complexes appears possible but is quite weak, according to the DFT calculations, for the two most reactive systems and not favorable at all for the BIPY system. An NMR investigation has not provided positive evidence for the presence of this interaction for water or methanol and the $\mathrm{Me}_{6}$ TREN system. Finally, the large extent of RRT for the $\mathrm{Et}_{3} \mathrm{NH}^{+}$proton donor, which is at the same time the strongest acid of the series and has no coordinating properties, indicates that RRT proceeds via an intermediate $\mathrm{Cu}^{\mathrm{II}}$ adduct, followed by protonolysis, rather than by an IS-PCET process, while a potential alternative OS-PCET is excluded by the solvent effect and by the redox potentials trend. A possible contribution of IS-PCET to RRT, however, cannot be excluded for proton donors able to coordinate to the metal center. ${ }^{31}$

Overall, while this study is consistent with the proposition, made in a previous contribution, ${ }^{28}$ that the saturated PMA-H made by reductive termination of $\mathrm{PMA}^{\bullet}$ chains in the presence of methanol in toluene solution may originate from the protonolysis of a PMA-Cu${ }^{\mathrm{II}} \mathrm{Br} / \mathrm{Me}{ }_{6} \mathrm{TREN}$ intermediate, the contribution (or dominance) of alternative PCET pathways cannot yet be totally excluded. In addition, we have shown in our study that, at least for the termination of the cyanoisopopyl radical, the $\mathrm{C}_{6} \mathrm{D}_{6}$ solvent does not contain sufficient amounts of water impurities to yield a significant impact of RRT, even for the most active $\mathrm{Cu}^{\mathrm{I} B r} / \mathrm{Me}_{6} \mathrm{TREN}$ system. Yet, the $\mathrm{PMA}^{\bullet}$ termination in the absence of methanol was shown in the previous contribution ${ }^{28}$ to yield dominant fraction of PMA-H product, not resulting from disproportionation. This puzzling result merits further studies, currently ongoing in our laboratories, which will be reported in a forthcoming contribution. Another puzzling result is that, although the occurrence of RRT (stoichiometrically oxidizing the ATRP activator complex $\mathrm{L} / \mathrm{Cu}^{\mathrm{I}}$ to an inactive $\mathrm{L} / \mathrm{Cu}^{\mathrm{II}} \mathrm{X}$ complex) is promoted by water and other proton donors, the complexes investigated in the present study are 
quite robust ATRP catalysts even in water, to give well-controlled halogen-capped macromolecules with high chain-end fidelity. A full understanding of how radicals interact with $\mathrm{L} / \mathrm{Cu}^{\mathrm{I}}$ complexes under polymerization conditions is paramount not only to rationalize the good performance of ATRP catalysts and possibly further improve them, but also for implementing polymerizations successfully controlled by only OMRP, which presents certain advantages in particular for less activated monomers, ${ }^{69-71}$ without interference of metal-catalyzed or mediated terminations (CRT or RRT).

\section{ASSOCIATED CONTENT}

Supporting Information. Details of the NMR determination of the product distribution, on the NMR investigation of the interaction of proton donors and $\mathrm{Cu}^{\mathrm{I}}$ complexes, and DFT results (Cartesian coordinates, energies, spin densities, optimized geometrical parameters) (18 pages).

\section{AUTHOR INFORMATION}

\section{Corresponding Author}

*Rinaldo Poli. rinaldo.poli@1cc-toulouse.fr.

\section{Author Contributions}

L.T. has carried out all the experimental work. R.P. has carried out the DFT calculations. The manuscript was written through contributions of all authors. All authors have given approval to the final version of the manuscript.

\section{Funding Sources}


Centre National de la Recherche Scientifique (CNRS): LIA “Laboratory of Coordination Chemistry for Controlled Radical Polymerization (LCC-CRP)”.

National Science Foundation (CHE 1707490).

\section{ACKNOWLEDGMENT}

We are grateful to the CNRS for funding this work via the International Associated Laboratory entitled "Laboratory of Coordination Chemistry for Controlled Radical Polymerization (LCCCRP)" and the National Science Foundation (grant CHE 1707490). We also gratefully acknowledge CALMIP (Calcul en Midi-Pyrénées) for granting access and free CPU time on the University of Toulouse mesocenter and the Ministère de l'Enseignement Supérieur et de la Recherche Scientifique (MESRS) for a Ph.D. fellowship to L.T.

\section{ABBREVIATIONS}

ATRP, atom transfer radical polymerization; CRT, catalytic radical termination; OMRP, organometallic-mediated radical polymerization; RRT, reductive radical termination; AIBN, azobis(isobutyronitrile); BIPY, 2,2'-bipyridine; Me$_{6}$ TREN, tris[2-(dimethylamino)ethyl]amine; TPMA, tris(2-pyridylmethyl)amine.

\section{REFERENCES}

1. Poli, R. Radical coordination chemistry and its relevance to metal-mediated radical polymerization. Eur. J. Inorg. Chem. 2011, 1513-1530.

2. Fischer, H. The Persistent Radical Effect: A Principle for Selective Radical Reactions and Living Radical Polymerizations. Chem. Rev. 2001, 101 (12), 3581-3610.

3. Jenkins, A. D.; Jones, R. G.; Moad, G. Terminology for reversible-deactivation radical polymerization previously called "controlled" radical or "living" radical polymerization (IUPAC Recommendations 2010). Pure Appl. Chem. 2010, 82 (2), 483-491 DOI: 10.1351/pac-rep-08-0403. 
4. Wang, J.-S.; Matyjaszewski, K. Controlled/"living" radical polymerization. Atom transfer radical polymerization in the presence of transition-metal complexes. J. Am. Chem. Soc. 1995, $117,5614-5615$.

5. Kato, M.; Kamigaito, M.; Sawamoto, M.; Higashimura, T. Polymerization of methyl methacrylate with the $\mathrm{CCl}_{4} /\left(\mathrm{PPh}_{3}\right)_{2} \mathrm{Cl}_{2} \mathrm{Ru}(\mathrm{II}) / \mathrm{MeAl}(\mathrm{ODBP})_{2}$ iniating system: possibility of living radical polymerization. Macromolecules 1995, 28, 1721-1723.

6. Matyjaszewski, K.; Tsarevsky, N. V. Macromolecular Engineering by Atom Transfer Radical Polymerization. J. Am. Chem. Soc. 2014, 136 (18), 6513-6533 DOI: 10.1021/ja408069v. 7. Ouchi, M.; Terashima, T.; Sawamoto, M. Transition Metal-Catalyzed Living Radical Polymerization: Toward Perfection in Catalysis and Precision Polymer Synthesis. Chem. Rev. 2009, 109 (11), 4963-5050.

8. Matyjaszewski, K. Advanced Materials by Atom Transfer Radical Polymerization. Advanced Materials 2018, 30 (23), DOI: 10.1002/adma.201706441.

9. Ribelli, T. G.; Lorandi, F.; Fantin, M.; Matyjaszewski, K. Atom Transfer Radical Polymerization: Billion Times More Active Catalysts and New Initiation Systems. Macromol. Rapid Comm. 2019, 40 (1), DOI: 10.1002/marc.201800616.

10. Poli, R. In Polymer Science: A Comprehensive Reference; Matyjaszewski, K., Möller, M., Ed.; Elsevier BV: Amsterdam, 2012; Vol. 3, pp 351-375.

11. Smith, K. M.; McNeil, W. S.; Abd-El-Aziz, A. S. Organometallic-Mediated Radical Polymerization: Developing Well-Defined Complexes for Reversible Transition Metal-Alkyl Bond Homolysis. Macromol. Chem. Phys. 2010, 211 (1), 10-16.

12. Allan, L. E. N.; Perry, M. R.; Shaver, M. P. Organometallic mediated radical polymerization. Progr. Polym. Sci. 2012, 37 (1), 127-156 DOI:

10.1016/j.progpolymsci.2011.07.004.

13. Le Grognec, E.; Claverie, J.; Poli, R. Radical Polymerization of Styrene controlled by Half-Sandwich Mo(III)/Mo(IV) Couples: all Basic Mechanisms are Possible. J. Am. Chem. Soc. 2001, 123, 9513-9524.

14. Poli, R. Relationship between one-electron transition metal reactivity and radical polymerization processes. Angew. Chem. Int. Ed. 2006, 45, 5058-5070.

15. Debuigne, A.; Poli, R.; Jérôme, C.; Jérome, R.; Detrembleur, C. Overview of cobaltmediated radical polymerization: roots, state of the art and future prospects. Prog. Polym. Sci. 2009, 34, 211-239.

16. Kaur, A.; Ribelli, T. G.; Schroeder, K.; Matyjaszewski, K.; Pintauer, T. Properties and ATRP Activity of Copper Complexes with Substituted Tris(2-pyridylmethyl)amine-Based Ligands. Inorg. Chem. 2015, 54 (4), 1474-1486 DOI: 10.1021/ic502484s.

17. Ribelli, T. G.; Fantin, M.; Daran, J.-C.; Augustine, K. F.; Poli, R.; Matyjaszewski, K. Synthesis and Characterization of the Most Active Copper-based ATRP Catalyst based on tris[(4-dimethylaminopyridyl)methyl]amine J. Am. Chem. Soc. 2018, 140, 1525-1534.

18. Schröder, K.; Konkolewicz, D.; Poli, R.; Matyjaszewski, K. Formation and Possible Reactions of an Organometallic Intermediate with Active Copper(I) Catalysts in an ATRP. Organometallics 2012, 31, 7994-7999.

19. Wang, Y.; Soerensen, N.; Zhong, M.; Schroeder, H.; Buback, M.; Matyjaszewski, K. Improving the "Livingness" of ATRP by Reducing $\mathrm{Cu}$ Catalyst Concentration. Macromolecules 2013, 46 (3), 683-691 DOI: 10.1021/ma3024393. 
20. Ribelli, T. G.; Rahaman, S. M. W.; Daran, J.-C.; Krys, P.; Matyjaszewski, K.; Poli, R. Effect of Ligand Structure on the Cu ${ }^{\mathrm{II}}-\mathrm{R}$ OMRP Dormant Species and its Consequences for Catalytic Radical Termination in ATRP. Macromolecules 2016, 49, 7749-7757.

21. Ribelli, T. G.; Augustine, K. F.; Fantin, M.; Krys, P.; Poli, R.; Matyjaszewski, K. Disproportionation or Combination? The Termination of Acrylate Radicals in ATRP. Macromolecules 2017, 50, 7920-7929.

22. Ribelli, T. G.; Rahaman, S. M. W.; Matyjaszewski, K.; Poli, R. In Reversible Deactivation Radical Polymerization: Mechanisms and Synthetic Methodologies; Tsarevsky, N., Gao, H., Matyjaszewski, K., Sumerlin, B., Ed.; American Chemical Society: Washington D.C., 2018; Chapter 6, Vol. 1284, pp 135-159.

23. Matyjaszewski, K. Radical nature of $\mathrm{Cu}$-catalyzed controlled radical polymerizations (atom transfer radical polymerization). Macromolecules 1998, 31, 4710-4717.

24. Bamford, C. H.; Jenkins, A. D. Termination reaction in vinyl polymerization Preparation of block copolymers. Nature 1955, 176 (4471), 78-78 DOI: 10.1038/176078a0.

25. Ayrey, G.; Humphrey, M. J.; Poller, R. C. Radiochemical studies of free-radical vinyl polymerizations. 7. Polymerization of methyl acrylate. Polymer 1977, 18 (8), 840-844 DOI: 10.1016/0032-3861(77)90192-6.

26. Szablan, Z.; Junkers, T.; Koo, S. P. S.; Lovestead, T. M.; Davis, T. P.; Stenzel, M. H.; Barner-Kowollik, C. Mapping photolysis product radical reactivities via soft ionization mass spectrometry in acrylate, methacrylate, and itaconate systems. Macromolecules 2007, 40 (19), 6820-6833 DOI: 10.1021/ma070626a.

27. Nakamura, Y.; Lee, R.; Coote, M. L.; Yamago, S. Termination Mechanism of the Radical Polymerization of Acrylates. Macromol. Rapid Comm. 2016, 37 (6), 506-513 DOI:

10.1002/marc.201500677.

28. Nakamura, Y.; Ogihara, T.; Yamago, S. Mechanism of $\mathrm{Cu}(\mathrm{I}) / \mathrm{Cu}(0)$-Mediated Reductive Coupling Reactions of Bromine-Terminated Polyacrylates, Polymethacrylates, and Polystyrene. ACS Macro Lett. 2016, 5 (2), 248-252 DOI: 10.1021/acsmacrolett.5b00947.

29. Krys, P.; Wang, Y.; Matyjaszewski, K.; Harrisson, S. Radical Generation and Termination in SARA ATRP of Methyl Acryalte: Effect of Solvent, Ligand and Chain Length. Macromolecules 2016, 49, 2977-2984.

30. Warren, J. J.; Tronic, T. A.; Mayer, J. M. Thermochemistry of Proton-Coupled Electron Transfer Reagents and its Implications. Chem. Rev. 2010, 110 (12), 6961-7001 DOI: $10.1021 / \mathrm{cr} 100085 \mathrm{k}$.

31. Kim, D.; Rahaman, S. M. W.; Mercado, B. Q.; Poli, R.; Holland, P. L. The Roles of Iron Complexes in Catalytic Radical Alkene Cross-Coupling. J. Am. Chem. Soc. in press.

32. Freiberg, M.; Mulac, W. A.; Schmidt, K. H.; Meyerstein, D. Reations of aliphatic free radicals with copper cations in aqueous solutions. 3. Reactions with cuprous ions - a pulse radiolysis study. J. Chem. Soc., Faraday Trans I 1980, 76, 1838-1848 DOI: 10.1039/f19807601838.

33. Sorek, Y.; Cohen, H.; Meyerstein, D. Kinetics od betah-hydroxy elimination reactions from the protoporphyrin iron(III)- $\mathrm{CHRCH}_{2} \mathrm{OH}$ complexes in aqueous solutions - a pulse radiolytic study. J. Chem. Soc., Faraday Trans I 1986, 82, 3431-3438 DOI: 10.1039/f19868203431.

34. Cohen, H.; Meyerstein, D. Kinetics of Formation and Decomposition of the Methyl Copper(II) Complex in Aqueous-Solutions - a Pulse-Radiolysis Study. Inorg. Chem. 1986, 25 (9), 1505-1506. 
35. Cohen, H.; Meyerstein, D. Kinetics of the reaction of copper(I) and copper(II) ions with 2,5-dioxacyclohexyl free radicals and homolysis of the aque-copper(II)-2,5-dioxacyclohexyl complex in aqueous solutions - a pulse radiolysis study. Inorg. Chem. 1987, 26 (14), 2342-2344 DOI: $10.1021 / \mathrm{ic} 00261 \mathrm{a} 037$.

36. Cohen, H.; Meyerstein, D. Kinetics of beta-hydroxyl elimination from $\left(\mathrm{H}_{2} \mathrm{O}\right)_{\mathrm{m}} \mathrm{Cu}^{\mathrm{II}} \mathrm{CH}_{2} \mathrm{C}\left(\mathrm{CH}_{3}\right)_{2} \mathrm{OH}^{+}$in aqueous solution - a pulse radiolysis study. J. Chem. Soc., Faraday Trans I 1988, 84, 4157-4160 DOI: 10.1039/f19888404157.

37. Goldstein, S.; Czapski, G.; Cohen, H.; Meyerstein, D. Formation and decomposition of transient complexes with a copper-carbon sigma bond in the reaction of copper(I) phenantroline with aliphatic free radicals - a pusle radiolysis study. Inorg. Chem. 1988, 27 (23), 4130-4135 DOI: 10.1021/ic00296a011.

38. Masarwa, M.; Cohen, H.; Saar, J.; Meyerstein, D. Metal induced decarboxylation of aliphatic free radicals. 1. Kinetics of the reactions of copper(I) and copper(II) ions with the 2methyl-2-carboxylacid-propyl free radical in aqueous solution - a pusle radiolysis study. Isr. $J$. Chem. 1990, 30 (4), 361-368.

39. Masarwa, M.; Cohen, H.; Meyerstein, D. Mechanism of oxidation of the 2hydroxycyclohexyl radical to cyclopentanecarbaldehyde by copper ions in aqueous solutions. Inorg. Chem. 1991, 30 (8), 1849-1854 DOI: 10.1021/ic00008a031.

40. Goldstein, S.; Czapski, G.; Cohen, H.; Meyerstein, D.; Cho, J. K.; Shaik, S. S. Deamination od 2-methyl-2-propanamine induced by hydroxyl radicals and metal ions - a comparison between the rates of betal-elimination of ammonia and water. Inorg. Chem. 1992, 31 (5), 798-803 DOI: 10.1021/ic00031a020.

41. Goldstein, S.; Czapski, G.; Cohen, H.; Meyerstein, D. Hydroxyl radical induced decarboxylation and deamination of 2-methylaniline catalyzed by copper ions. Inorg. Chem. 1992, 31 (12), 2439-2444 DOI: 10.1021/ic00038a026.

42. Goldstein, S.; Czapski, G.; Cohen, H.; Meyerstein, D. Deamination of beta-alanine induced by hydroxyl radicals and monovalent copper ions - a pulse radiolysis study Inorg. Chim. Acta 1992, 192 (1), 87-93 DOI: 10.1016/s0020-1693(00)83177-1.

43. Navon, N.; Golub, G.; Cohen, H.; Meyerstein, D. Kinetics and Reaction-Mechanisms of Copper(I) Complexes with Aliphatic Free-Radicals in Aqueous-Solutions - a Pulse-Radiolysis Study. Organometallics 1995, 14 (12), 5670-5676.

44. Szulc, A.; Meyerstein, D.; Cohen, H. Monovalent copper as a potential catalyst for formation of acetaldehyde via the migration of methyl radicals to the coordinated carbonyl in the complex (CO)Cu-II-CH3+. Inorg. Chim. Acta 1998, 270 (1-2), 440-445 DOI: 10.1016/s00201693(97)06001-5.

45. Ribelli, T. G.; Matyjaszewski, K.; Poli, R. The interaction of carbon-centered radicals with copper(I) and copper(II) complexes. J. Coord. Chem. 2018, 71, 1641-1668.

46. Saba, S.; Hernandez, R.; Choy, C. C.; Carta, K.; Bennett, Y.; Bondi, S.; Kolaj, S.; Bennett, C. A simple and efficient one-step protocol for the preparation of alkyl-substituted ammonium tetrafluoroborate and hexafluorophosphate salts. J. Fluorine Chem. 2013, 153, 168171 DOI: 10.1016/j.jfluchem.2013.05.007.

47. Frisch, M. J.; Trucks, G. W.; Schlegel, H. B.; Scuseria, G. E.; Robb, M. A.; Cheeseman, J. R.; Scalmani, G.; Barone, V.; Mennucci, B.; Petersson, G. A.; Nakatsuji, H.; Caricato, M.; Li, X.; Hratchian, H. P.; Izmaylov, A. F.; Bloino, J.; Zheng, G.; Sonnenberg, J. L.; Hada, M.; Ehara, M.; Toyota, K.; Fukuda, R.; Hasegawa, J.; Ishida, M.; Nakajima, T.; Honda, Y.; Kitao, O.; Nakai, H.; Vreven, T.; Montgomery Jr., J. A.; Peralta, J. E.; Ogliaro, F.; Bearpark, M.; Heyd, J. 
J.; Brothers, E.; Kudin, K. N.; Staroverov, V. N.; Kobayashi, R.; Normand, J.; Raghavachari, K.; Rendell, A.; Burant, J. C.; Iyengar, S. S.; Tomasi, J.; Cossi, M.; Rega, N.; Millam, N. J.; Klene, M.; Knox, J. E.; Cross, J. B.; Bakken, V.; Adamo, C.; Jaramillo, J.; Gomperts, R.; Stratmann, R. E.; Yazyev, O.; Austin, A. J.; Cammi, R.; Pomelli, C.; Ochterski, J. W.; Martin, R. L.;

Morokuma, K.; Zakrzewski, V. G.; Voth, G. A.; Salvador, P.; Dannenberg, J. J.; Dapprich, S.; Daniels, A. D.; Farkas, Ö.; Foresman, J. B.; Ortiz, J. V.; Cioslowski, J.; Fox, D. J. Gaussian 09, Revision D.01. Gaussian, Inc.: Wallingford CT, 2009.

48. Perdew, J. P. Density-Functional Approximation for the Correlation-Energy of the Inhomogeneous Electron-Gas. Phys. Rev. B 1986, 33 (12), 8822-8824.

49. Ehlers, A. W.; Böhme, M.; Dapprich, S.; Gobbi, A.; Hoellwarth, A.; Jonas, V.; Koehler, K. F.; Stegmann, R.; Veldkamp, A.; Frenking, G. A set of f-polarization functions for pseudopotential basis sets of the transition metals Sc-Cu, Y-Ag and La-Au. Chem. Phys. Lett. 1993, 208 (1-2), 111-114.

50. Grimme, S.; Antony, J.; Ehrlich, S.; Krieg, H. A consistent and accurate ab initio parametrization of density functional dispersion correction (DFT-D) for the 94 elements H-Pu. $J$. Chem. Phys. 2010, 132 (15), 154104 DOI: 10.1063/1.3382344.

51. Marenich, A. V.; Cramer, C. J.; Truhlar, D. G. Universal Solvation Model Based on Solute Electron Density and on a Continuum Model of the Solvent Defined by the Bulk Dielectric Constant and Atomic Surface Tensions. J. Phys. Chem. B 2009, 113 (18), 6378-6396 DOI: $10.1021 / \mathrm{jp} 810292 \mathrm{n}$.

52. Bryantsev, V. S.; Diallo, M. S.; Goddard, W. A., III. Calculation of solvation free energies of charged solutes using mixed cluster/continuum models. J. Phys. Chem. B 2008, 112 (32), 9709-9719 DOI: 10.1021/jp802665d.

53. Braunecker, W. A.; Tsarevsky, N. V.; Pintauer, T.; Gil, R. R.; Matyjaszewski, K. Quantifying vinyl monomer coordination to $\mathrm{Cu}^{\mathrm{I}}$ in solution and the effect of coordination on monomer reactivity in radical copolymerization. Macromolecules 2005, 38 (10), 4081-4088.

54. Krstina, J.; Moad, G.; Willing, R. I.; Danek, S. K.; Kelly, D. P.; Jones, S. L.; Solomon, D. $\mathrm{H}$. Further studies on the thermal decomposition of AIBN - Implications concerning the mechanism of termination in methacrylonitrile polymerization. Eur. Polym. J. 1993, 29 (2-3), 379-388 DOI: 10.1016/0014-3057(93)90108-r.

55. Bamford, C. H.; Dyson, R. W.; Eastmond, G. C. Network formation. 4. Nature of termination reaction in free-radical polymerization. Polymer 1969, 10 (11), 885-899 DOI: 10.1016/0032-3861(69)90120-7.

56. Eckenhoff, W. T.; Garrity, S. T.; Pintauer, T. Highly efficient copper-mediated atomtransfer radical addition (ATRA) in the presence of reducing agent. Eur. J. Inorg. Chem. 2008, (4), 563-571.

57. Eckenhoff, W. T.; Pintauer, T. Structural Comparison of Copper(I) and Copper(II) Complexes with Tris(2-pyridylmethyl)amine Ligand. Inorg. Chem. 2010, 49 (22), 10617-10626 DOI: $10.1021 /$ ic1016142.

58. Braunecker, W. A.; Tsarevsky, N. V.; Gennaro, A.; Matyjaszewski, K. Thermodynamic Components of the Atom Transfer Radical Polymerization Equilibrium: Quantifying Solvent Effects. Macromolecules 2009, 42 (17), 6348-6360 DOI: 10.1021/ma901094s.

59. Moore, J. W.; Pearson, R. G. Kinetics and Mechanisms. $3^{\text {rd }}$ ed.; John Wiley \& Sons: New York, 1981. 
60. Ribelli, T. G.; Krys, P.; Cong, Y. D.; Matyjaszewski, K. Model Studies of Alkyl Halide Activation and Comproportionation Relevant to RDRP in the Presence of $\mathrm{Cu}-0$. Macromolecules 2015, 48 (23), 8428-8436 DOI: 10.1021/acs.macromol.5b01952.

61. Fulmer, G. R.; Miller, A. J. M.; Sherden, N. H.; Gottlieb, H. E.; Nudelman, A.; Stoltz, B. M.; Bercaw, J. E.; Goldberg, K. I. NMR Chemical Shifts of Trace Impurities: Common Laboratory Solvents, Organics, and Gases in Deuterated Solvents Relevant to the Organometallic Chemist. Organometallics 2010, 29 (9), 2176-2179 DOI: 10.1021/om100106e.

62. Debuigne, A.; Champouret, Y.; Jérôme, R.; Poli, R.; Detrembleur, C. Mechanistic Insights into Cobalt Mediated Radical Polymerization (CMRP) of Vinyl Acetate via Cobalt(III) Adducts as Initiators. Chem. Eur. J. 2008, 14, 4046-4059.

63. Tellers, D. M.; Ritter, J. C. M.; Bergman, R. G. Synthesis of iridium(III) carboxamides via the bimetallic reaction between $\mathrm{Cp}^{*}\left(\mathrm{PMe}_{3}\right) \operatorname{IrPh}(\mathrm{OH})$ and $\left[\mathrm{Cp}^{*}\left(\mathrm{PMe}_{3}\right) \operatorname{Ir}(\mathrm{Ph}) \mathrm{NCR}\right]^{+}$. Inorg. Chem. 1999, 38, 4810-4818.

64. Fulton, J. R.; Bouwkamp, M. W.; Bergman, R. G. Reactivity of a parent amidoruthenium complex: A transition metal amide of exceptionally high basicity. J. Am. Chem. Soc. 2000, 122 (36), 8799-8800.

65. Fulton, J. R.; Sklenak, S.; Bouwkamp, M. W.; Bergman, R. G. A comprehensive investigation of the chemistry and basicity of a parent amidoruthenium complex. J. Am. Chem. Soc. 2002, 124 (17), 4722-4737.

66. Tehranchi, J.; Donoghue, P. J.; Cramer, C. J.; Tolman, W. B. Reactivity of (Dicarboxamide) M-II-OH (M = Cu, Ni) Complexes - Reaction with Acetonitrile to Yield M(II)Cyanomethides. Eur. J. Inorg. Chem. 2013, 2013 (22-23), 4077-4084 DOI: 10.1002/ejic.201300328.

67. Bortolamei, N.; Isse, A. A.; Di Marco, V. B.; Gennaro, A.; Matyjaszewski, K. Thermodynamic Properties of Copper Complexes Used as Catalysts in Atom Transfer Radical Polymerization. Macromolecules 2010, 43 (22), 9257-9267.

68. Cuvigny, T.; Leborgne, J. F.; Larcheveque, M.; Normant, H. Hyperbasic media. 1. Metalation of hydrazones - direct synthesis of nitriles. Synthesis-Stuttgart 1976, (4), 237-238.

69. Morin, A. N.; Detrembleur, C.; Jérôme, C.; Tullio, P. D.; Poli, R.; Debuigne, A. Effect of head-to-head addition in vinyl acetate reversible deactivation radical polymerization: why is Co(acac)2-mediated polymerization so much better? Macromolecules 2013, 46, 4303-4312. 70. Poli, R. New phenomena in organometallic-mediated radical polymerization (OMRP) and perspectives for control of less active monomers. Chem. Eur. J. 2015, 21, 6988-7001. 71. Banerjee, S.; Ladmiral, V.; Debuigne, A.; Detrembleur, C.; Poli, R.; Améduri, B. Organometallic Mediated Radical Polymerization of Vinylidene Fluoride. Angew. Chem. Int. Ed. 2018, 57, 2934-2937.

SYNOPSIS. Highly reducing copper(I) complexes with the Me ${ }_{6}$ TREN and TPMA ligands, and to a lesser extent even the less reducing system stabilized by 2,2 '-bipyridine, can trap the stabilized cyanoisopropyl radical from AIBN to form preferentially the N-bound keteniminato derivative, followed by reduction to isobutyronitrile in the presence of proton donors. 
TOC IMAGE:

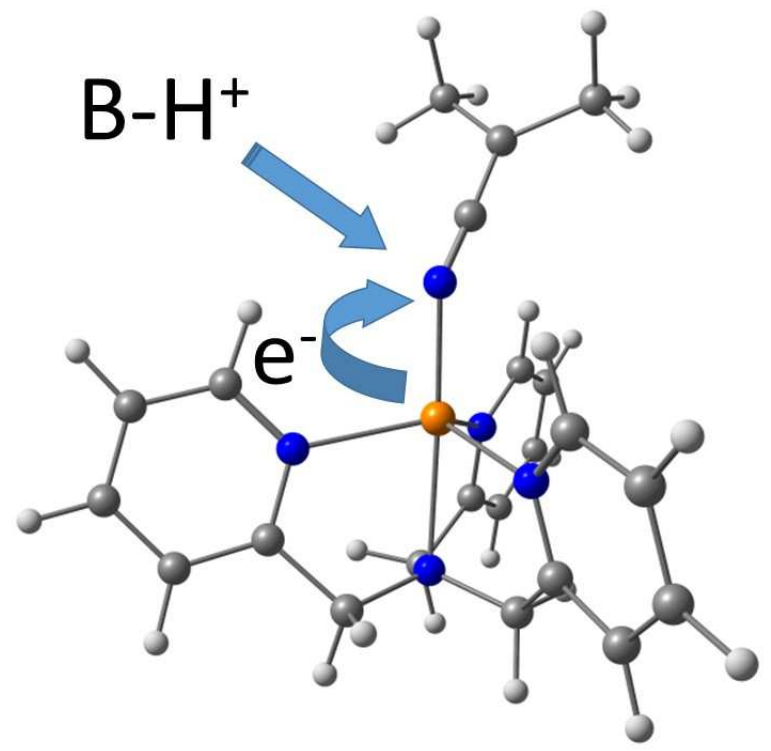

